\title{
The E1B 19K protein blocks apoptosis by interacting with and inhibiting the p53- inducible and death-promoting Bax protein
}

\author{
Jeonghoon Han, ${ }^{1}$ Peter Sabbatini, ${ }^{1}$ Denise Perez, ${ }^{1}$ Lakshmi Rao, ${ }^{1}$ Digant Modha, ${ }^{1}$ \\ and Eileen White ${ }^{1,2,3}$ \\ ${ }^{1}$ Center for Advanced Biotechnology and Medicine and ${ }^{2}$ Department of Biological Sciences and the Cancer Institute of New \\ Jersey; Rutgers University, Piscataway, New Jersey 08854 USA
}

\begin{abstract}
The E1B 19K protein is a potent apoptosis inhibitor and the putative adenovirus Bcl-2 homolog. To investigate the mechanism of apoptosis regulation, 19K-interacting cellular proteins were identified using the yeast two-hybrid system, and Bax was one of seven 19K-interacting clones. Residues 50-78 of Bax containing a conserved region designated Bcl-2 homology region 3 (BH3) were sufficient for specific binding to both the E1B 19K and Bcl-2 proteins. The Bax-E1B 19K interaction was detectable in vitro and in lysates from mammalian cells, and Bax expression antagonized E1B 19K protein function. bax mRNA and protein levels were p53-inducible with kinetics identical to that of $p 21 /$ Waf-1/Cip-1, and E1B $19 \mathrm{~K}$ and Bcl-2 expression did not affect Bax or p21/Waf-1/Cip-1 accumulation. In cells where p53 was mutant, Bax expression induced apoptosis, suggesting that Bax was sufficient for apoptosis, and acted downstream of p53. p53 may simultaneously activate the transcription of genes required for both growth arrest $(p 21 / W a f-1 / C i p-1)$ and death $(b a x)$, and E1B 19K and Bcl-2 may act distally and function through interaction with and antagonism of Bax to prevent apoptosis. With the death pathway disabled, induction of growth arrest by p53 can then be manifested.
\end{abstract}

[Key Words: Apoptosis; Bcl-2; E1B19K; p53; Bax; cell death]

Received October 12, 1995; accepted in revised form December 18, 1995.

Expression of the adenovirus ${ }^{1}$ E1A gene stimulates host cell DNA synthesis, which creates a suitable environment for viral DNA replication (Moran 1993). The induction of DNA synthesis by ElA, however, cosegregates with the induction of apoptosis (White et al. 1991; Mymryk et al. 1994; Teodoro et al. 1995), which is responsible for impairing virus production (White 1994, 1995). The ability of ElA to induce apoptosis in rodent cells is p53-dependent. ElA expression causes p53 accumulation by increasing the half-life of $\mathrm{p} 53$ protein (Lowe and Ruley 1993; Chiou et al. 1994b|, ElA transforms p53 $-/$ - but not p53 + / + mouse embryo fibroblasts (Lowe et al. 1994), and dominant-interfering mutant forms of p53 block the induction of apoptosis by E1A (Debbas and White 1993). Furthermore, BRK cells transformed by E1A and the temperature-sensitive p53(val135) [tsp53(val135)] proliferate at the restrictive temperature when p53 is predominantly in the mutant conformation and undergo apoptosis at the permissive temperature when p53 is predominantly wild type (Debbas and White 1993; Chiou et al. 1994a; Lin et al. 1995; Sabbatini et al. $1995 \mathrm{~b})$. Thus, functional p53 is required for E1A-induced apoptosis.

${ }^{3}$ Corresponding author. p53 is the most commonly mutated gene in human tumors (Hollstein et al. 1991; Vogelstein 1990) and encodes a transcription factor capable of both repression and trans-activation (Prives 1994). It is clear that p53 has a role in the induction of growth arrest through the trans-activation of the $p 21 /$ Waf-1/Cip-1 gene, the product of which inhibits cell cycle-dependent kinases (ElDeiry et al. 1993; Harper et al. 1993; Xiong et al. 1993; Noda et al. 1994/ which may contribute to the tumor suppression activity of p53.

Another mechanism by which p53 could act as a tumor suppressor is realized with the observation that in some circumstances p53 does not induce growth arrest but, rather, cell death through apoptosis (Yonish-Rouach et al. 1991). Thus, p53 can function as a tumor suppressor by inducing either growth arrest or cell death, depending on the physiological circumstances. p53 may be a cellular surveillance factor that responds to DNA damage or the deregulation of cell growth control, as is the case with E1A. p53 may thereby play an important role in triggering cell death as a means of eliminating virusinfected or transformed cells.

How p53 implements the apoptotic program is still not clear and may differ with varying physiological circumstances. In BRK cells transformed by E1A and the 
tsp53(val135), the activity of p53 as a transcription factor is required for apoptosis. Inactivating mutations in the transcriptional activation domain of p53 prevent induction of apoptosis when p53 assumes the wild-type conformation (Sabbatini et al. 1995b). In this setting p53 may activate the transcription of death genes or repress the transcription of survival genes to promote apoptosis.

To prevent the detrimental ElA-induced, p53-dependent apoptosis, the adenovirus-encoded ElB gene produces two different gene products, E1B 55K and E1B 19K, to disable p53 function. Although it is clear that E1B $55 \mathrm{~K}$ blocks the function of p53 by complexing with and inhibiting transcriptional activity of p53 (Sarnow et al. 1982; Yew and Berk 1992), the mechanism by which E1B $19 \mathrm{~K}$ inhibits p53-mediated apoptosis has not been determined. However, the E1B $19 \mathrm{~K}$ protein does share functional and structural homology with Bcl-2, suggesting that the two proteins may act by similar mechanisms to inhibit apoptosis (Rao et al. 1992; Boyd et al. 1994; Chiou et al. 1994b).

The E1B 19K and Bcl-2 proteins are functionally interchangeable in a variety of different settings. Bcl-2, for example, will substitute for the E1B $19 \mathrm{~K}$ protein and will cooperate with E1A to transform rodent cells (Rao et al. 1992). Both the E1B 19K and Bcl-2 proteins block apoptosis induced by p53 (Chiou et al. 1994a; Lin et al. 1995; Sabbatini et al. 1995a), and Bcl-2 will functionally substitute for the E1B $19 \mathrm{~K}$ protein during adenovirus infection of human cells (Tarodi et al. 1993; Chiou et al. 1994b). However, the E1B 19K protein is more effective at inhibiting apoptosis mediated by tumor necrosis factor $\alpha$ (TNF- $\alpha$ ) and Fas antigen (Gooding et al. 1991; Hashimoto et al. 1991; White et al. 1992). Thus, the E1B 19K protein is an apoptosis inhibitor and is functionally very similar to Bcl-2, suggesting that the $19 \mathrm{~K}$ protein may be a member of the Bcl-2 family of apoptosis regulators (Chiou et al. 1994b).

The E1B 19K protein shares limited sequence homology with other members of the Bcl-2 family. The highly conserved central region of the E1B $19 \mathrm{~K}$ protein has been defined by mutational analysis to be important in transformation and regulation of apoptosis (White et al. 1992; Chiou et al. 1994b). A comparison of the amino acid sequence of Bcl-2 and E1B $19 \mathrm{~K}$ proteins has indicated amino acid sequence homology in the region of $19 \mathrm{~K}$ known to be important for structure and function, particularly within $\mathrm{Bcl}-2$ homology region 1 (BH1)/White et al. 1992; Chiou et al. 1994b).

The E1B 19K and Bcl-2 proteins also share the ability to block apoptosis induced by $\mathrm{p} 53$. The introduction of an $\mathrm{E} 1 \mathrm{~B} 19 \mathrm{~K}$ or $\mathrm{Bcl}-2$ expression vector into ElA plus tsp53/vall35)-transformed BRK cell lines completely prevents the induction of apoptosis by p53 at the permissive temperature and causes cells to remain in a growtharrested state (Debbas and White 1993; Chiou et al. 1994a; Lin et al. 1995; Sabbatini et al. 1995a). There is a complete cessation of DNA synthesis with growth arrest occurring primarily in the $G_{2}$ phase of the cell cycle (Chiou et al. 1994a; Lin et al. 1995). Thus, E1B 19K and $\mathrm{Bcl}-2$ proteins are functionally interchangeable for block- ing p53-mediated apoptosis, but the p53-dependent growth arrest function remains intact, suggesting that the apoptosis and growth arrest functions of p53 are separable.

Because the biochemical mechanism of E1B 19K protein function was unknown, we screened a HeLa cell cDNA library using the yeast two-hybrid system for E1B $19 \mathrm{~K}$-interacting proteins. We demonstrate here that one of the E1B $19 \mathrm{~K}$ binding proteins is Bax. Bax was identified previously as a Bcl-2-interacting protein that prevents inhibition of apoptosis by Bcl-2 (Oltvai et al. 1993). Bax similarly antagonizes the ability of the $19 \mathrm{~K}$ protein to inhibit apoptosis. Furthermore, bax is p53-inducible and sufficient for activating the apoptosis pathway in the absence of functional p53. p53 may act as a tumor suppressor by inducing the transcription of genes required for both apoptosis and growth arrest. Bcl-2 and E1B 19K proteins may function by inhibiting apoptosis through specific Bax interaction and thereby control the physiological outcome of p53 function.

\section{Results}

Isolation of Bax from a two-hybrid screen for E1B $19 \mathrm{~K}$-interacting proteins

To identify E1B 19K-binding proteins that may play a critical role in the regulation of apoptosis, we screened a HeLa cell cDNA library constructed in the pGAD-GH vector, which has cDNA library sequences fused to the GAL4 activation domain. The bait plasmid consisted of the $E 1 B 19 \mathrm{~K}$ open reading frame fused to the sequence for the yeast GAL4 DNA-binding domain in the pGBT-9 vector. Three million transformants were screened for growth in the absence of histidine and production of $\beta$-galactosidase by an X-gal filter assay. Seven positive clones (Bpl-7) that interacted strongly with the E1B 19K protein did not show the interaction when combined with the pGBT-9 vector alone or an irrelevant gene (apc2) in pGBT-9, indicating specificity for interaction with the E1B 19K protein (Fig. 1). Sequence analysis of the clones revealed that $\mathrm{Bp} 3$ was identical in sequence with part of exon 3 of human $b a x$ ( $h b a x$ ) encoding amino acids $50-78$ in frame with the activation domain of GAL4 (see Fig. 1C). The exon 3 sequences in $\mathrm{Bp} 3$ were followed by a novel open reading frame encoding 30 additional amino acids (designated exon $4^{\prime}$ ) prior to a stop codon. bax exon 4 sequences were followed out of frame before reaching an untranslated region and polyadenylation sequence (Fig. 1C).

The strong interaction of $\mathrm{Bp} 3$ with $\mathrm{E} 1 \mathrm{~B} 19 \mathrm{~K}$ in the two-hybrid system suggested that residues $50-78$ of bax exon 3 may encode the E1B 19K-binding site. For this reason, two pGAD-GH constructs were generated: one that encoded residues $50-78$ of bax exon 3 with the novel exon 4' sequences but without the untranslated region including exon $4\left(\mathrm{Bp} 3-\mathrm{Ex} 3 / 4^{\prime}\right)$; and the second encoded only residues $50-78$ of bax exon 3 (Bp3-Ex3). Both constructs showed strong interactions with the $19 \mathrm{~K}$ protein (Fig. 1A for Bp3-Ex3; data not shown for Bp3- 
A

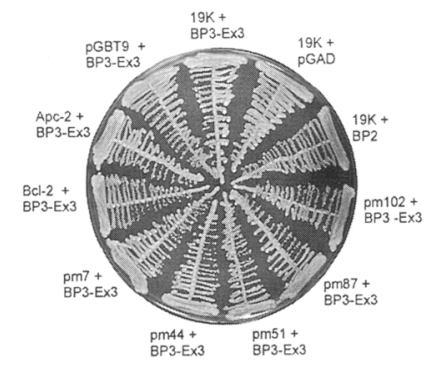

With Histidine

B

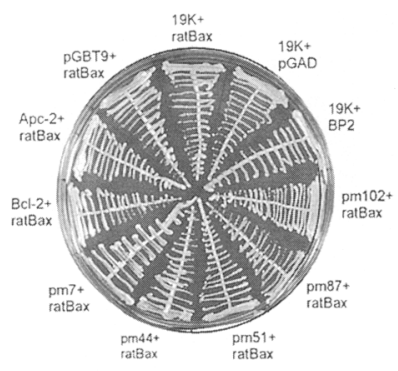

With Histidine

C

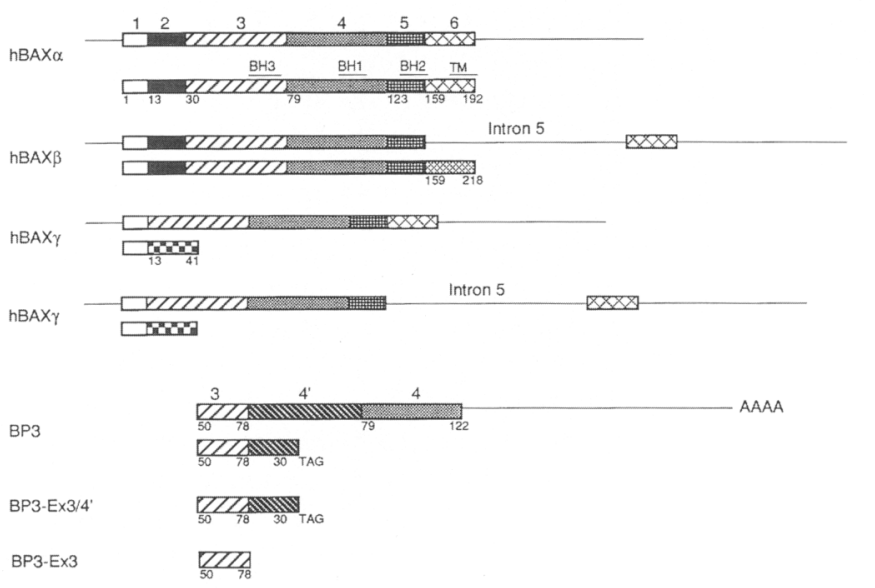

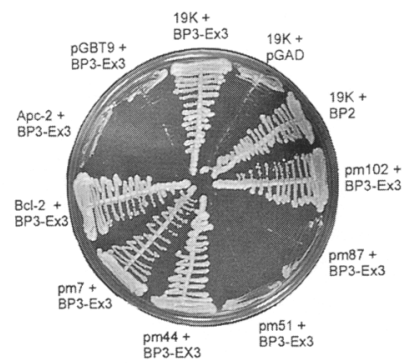

Without Histidine

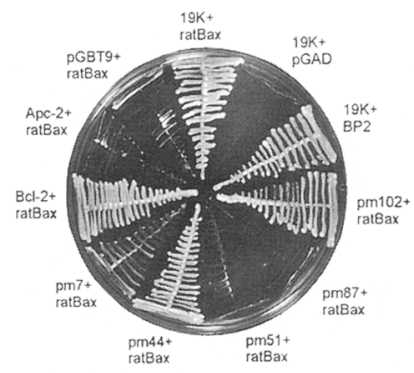

Without Histidine
Figure 1. Interaction of the E1B 19K protein with Bax in yeast. (A) Two-hybrid interaction assay in yeast strain YGH1 with plasmids expressing the GAL4 activating domain-Bp3-Ex3 (amino acid $50-78$ of hBax) fusion protein in combination with plasmids expressing a GAL4 DNA-binding domain (pGBT-9) fused to either the ElB $19 \mathrm{~K}$ protein $(19 \mathrm{~K})$, an irrelevant protein (Apc-2), the full-length Bcl-2 protein (Bcl2), or the E1B 19K missense mutants pm7, pm44, pm51 (BH3 mutant), pm87 (BH1 mutant), and pm102. Bp2 is located 252 amino acids to the carboxyl terminus of lamin A fused to the activation domain of GAL4, which was also isolated from the two-hybrid screen based on the ability to interact with the E1B $19 \mathrm{~K}$ protein. pGAD$\mathrm{GH}$ is the control vector expressing the GAL4 activation domain alone. The thistidine plate lacks only leucine and tryptophan, thus selecting only for the presRNA 1.okb ence of pGAD-GH and pGBT-9. The - his$192 A \mathrm{~A} 21 \mathrm{kd}$ tidine plate lacks leucine, tryptopan, and histidine, thus selecting not only for the presence of the two plasmids but also for the interaction of the plasmid-encoded fusion proteins. $(B)$ Two-hybrid interaction assay in yeast strain $\mathrm{YGHl}$ with plasmids expressing the GAL4 activating domain$\mathrm{rBax}$ fusion protein in combination with the plamids described above. $(C)$ Schematic representation of alternative transcripts of bax and their predicted protein products. Exons are indicated by boxes. Because of the alternative splicing of exon 2 in Bax $\gamma$, exon 3 in Bax $\gamma$ is different from exon 3 in $B a x \alpha$, as indicated by the different shading pattern. The $\mathrm{BH} 3, \mathrm{BH} 1$, and $\mathrm{BH} 2$ conserved regions of the Bcl-2 family are indicated. (TM) The transmembrane region. (BP3) The Bax segment isolated from the twohybrid screen for $19 \mathrm{~K}$ association. Bp3Ex3/4' and Bp3-Ex3 constructs were derived from $\mathrm{BP} 3$ as indicated. $1+++\mid$ Interaction of Bax constructs with the E1B 19K protein in yeast as in $A$ and $B .(D)$ Amino acid sequence alignment of the $\mathrm{BH} 3$ region among members of the Bcl-2 family.
Ex3/4'). Moreover, all three constructs (Bp3, Bp3-Ex3/ $4^{\prime}, \mathrm{Bp} 3-\mathrm{Ex} 3$ ) displayed equally strong interactions with $\mathrm{Bcl}-2$ in yeast (Fig. 1A for Bp3-Ex3; data not shown for $\mathrm{Bp} 3-\mathrm{Ex} 3 / 4^{\prime}$ and $\mathrm{Bp} 3$ |, suggesting that the binding requirements for both $19 \mathrm{~K}$ and Bcl-2 were similar, if not identical, and Bp3-Ex3 was sufficient for the interaction to occur in yeast.

Because Bp3, Bp3-Ex3, and Bp3-Ex3/4' all encode seg- ments of Bax, interaction of the E1B $19 \mathrm{~K}$ protein with full-length Bax was evaluated. Full-length rat $b a x \alpha$ (rbax) was cloned by reverse transcription and PCR of mRNA from the BRK cell line p53Anl (Debbas and White 1993) and was tested for interaction with the E1B $19 \mathrm{~K}$ protein in yeast (Fig. 1B). rBax possessed the same capacity to interact with the $19 \mathrm{~K}$ protein as Bp3-Ex3 and other Bax constructs (Fig. 1B). As expected, full-length 
rBax also interacted with Bcl-2 (Fig. 1B). Thus, rBax interacted with $\mathrm{E} 1 \mathrm{~B} 19 \mathrm{~K}$ and residues $50-78$ of Bax were sufficient for interaction not only with the E1B $19 \mathrm{~K}$ protein but also the Bcl-2 protein in yeast.

\section{Sequence requirements within the $E 1 B 19 \mathrm{~K}$ protein for Bax interaction}

The interaction of Bax with specific E1B 19K mutants known to be defective for E1B $19 \mathrm{~K}$ function and/or structure was used as a measure of the specificity of the interaction. We tested the ability of the four constructs (Bp3, Bp3-Ex3, Bp3-Ex3/4', and rBax in pGAD) to interact with missense mutants of the E1B $19 \mathrm{~K}$ protein (pm7, pm44, pm51, pm87, and pm 102) which resulted in a loss of transforming activity and the ability to block apoptosis induced by TNF- $\alpha$ and Fas antigen (White et al. 1992; Chiou et al. 1994b).

Substitution of either phenylalanine for serine at position $51(\mathrm{pm} 51)$ or glycine for alanine at position 87 (pm87) in the E1B 19K protein resulted in loss of the ability to interact with Bp3, Bp3-Ex3, Bp3-Ex3/4', and rBax in pGAD in yeast (Fig. 1). pm7, pm44, and pm102, however, maintained the ability to interact with the Bax constructs, except that $\mathrm{pm} 7$ interacted more weakly with rBax (Fig. 1). pm87 has a replacement of a highly conserved glycine $(100 \%$ identical across all 12 adenovirus serotypes/ with alanine in the region of the $19 \mathrm{~K}$ protein homologous to BHl (White et al. 1992; Chiou et al. 1994b). The same glycine to alanine substitution in $\mathrm{BH}$ of $\mathrm{Bcl}-2$ prevents both $\mathrm{Bcl}-2$ function and Bcl-2-Bax interaction (Yin et al. 1994). Thus, the equivalent BH1 mutation in the E1B $19 \mathrm{~K}$ protein (pm87) also prevents Bax interaction. pm51 is located within another highly conserved region of the E1B $19 \mathrm{~K}$ protein and other members of the Bcl-2 family that we have designated Bcl-2 homology region 3 (BH3) (Fig. $1 \mathrm{C}$ and $\mathrm{D}$ ). The $\mathrm{BH} 3$ region is also included in residues 50-78 of Bax, which is sufficient for the $19 \mathrm{~K}$ protein interaction in yeast. Thus, sequence information within $\mathrm{BH} 3$ of Bax is necessary and sufficient for interaction with the ElB $19 \mathrm{~K}$ and Bcl-2 proteins. Likewise, sequence information within $\mathrm{BH} 3$ of the $\mathrm{E} 1 \mathrm{~B}$ $19 \mathrm{~K}$ protein is apparently also required for interaction with Bax.

Having established that point mutations in pm51 and pm87 result in a loss of interaction between E1B 19K and Bax (Fig. 1), we made further deletions in the E1B 19K protein to map the minimal region sufficient for the interaction. Sequential deletions from both the amino-terminal $(\Delta \mathrm{N} 30, \Delta \mathrm{N} 64$, and $\Delta \mathrm{N} 87)$ and carboxy-terminal $(\Delta C 146, \Delta C 93, \Delta C 70)$ ends were generated in addition to four mutants with deletions of both amino- and carboxyterminal ends $(30-146,30-93,64-146,19-57)$ (Fig. 2). Both full-length $\mathrm{rBax}$ and Bp3-Ex3 were tested with the E1B $19 \mathrm{~K}$ deletion mutants in the two-hybrid system. Interactions were confirmed by the ability of yeast to grow in the absence of histidine and turn blue in a $\beta$-galactosidase assay.

Deletions of either the amino-terminal 64 residues
$(\Delta \mathrm{N} 64)$ or the carboxy-terminal 30 amino acids $(\Delta \mathrm{C} 146)$ of the E1B $19 \mathrm{~K}$ protein still permitted interaction with Bp3-Ex3 as effectively as the wild-type E1B 19K protein (Fig. 2). Correspondingly, the central domain containing deletion 30-146 was sufficient for the interaction, whereas larger deletions of either the amino or carboxyl terminus of the E1B $19 \mathrm{~K}$ protein were not capable of interacting with Bp3-Ex3 (Fig. 2). Thus, the minimal region of the E1B $19 \mathrm{~K}$ protein required for binding to Bp3Ex3 maps to the central conserved domain, including $\mathrm{BH} 1, \mathrm{BH} 2$, and $\mathrm{BH} 3$ (Fig. 2). Interestingly, the 19-57 fragment of the E1B $19 \mathrm{~K}$ protein that corresponds to Bp3Ex3 did not interact with Bp3-Ex3 (Fig. 2). The inability of equivalent regions with the $19 \mathrm{~K}$ and Bax proteins to interact suggests that protein-protein interactions may be nonsymmetrical.

Interaction of the E1B $19 \mathrm{~K}$ protein with full-length rBax produced somewhat different results. None of the E1B $19 \mathrm{~K}$ deletions that interacted with Bp3-Ex3 ( $\triangle$ N64, $\Delta \mathrm{Cl} 146$, or 30-146) interacted with full-length $\mathrm{rBax}$ (Fig. 2). The $19 \mathrm{~K}$ deletion $19-57$ containing BH3, however, was sufficient for interacting with full-length $\mathrm{rBax}$, albeit weakly (Fig. 2). None of the other deletions, all of which lack the BH3 region, showed any interaction. Taken together, these results suggest that the $\mathrm{BH} 3$ region is required but not sufficient for establishing the interaction between ElB $19 \mathrm{~K}$ and Bax proteins.

\section{E1B $19 \mathrm{~K}$ associates with Bax in vitro and in cell lysates}

In parallel with the yeast two-hybrid assay for $19 \mathrm{~K}-\mathrm{Bax}$ interaction, we examined the ability of the E1B $19 \mathrm{~K}$ and Bax proteins to interact in vitro. hBcl-2, ElB 19K, and rBax were prepared by in vitro transcription and cotranslation and assayed for the ability to coimmunoprecipitate. Following cotranslation, the ${ }^{35} \mathrm{~S}$-labeled hBcl-2, E1B $19 \mathrm{~K}$, and rBax proteins were incubated in specific combination with antibodies directed against $\mathrm{Bcl}-2(\Delta \mathrm{C} 21)$, Bax (N-20), and E1B 19K (p21) proteins. The Bcl-2 antibody precipitated in vitro-synthesized $\mathrm{Bcl}-2$ protein but not the E1B 19K and Bax proteins (Fig. 3A). When the E1B $19 \mathrm{~K}$ and Bcl-2 proteins were cotranslated, the Bcl-2 antibody did not pull out the E1B $19 \mathrm{~K}$ protein, indicating that there is no interaction between the $\mathrm{Bcl}-2$ and $19 \mathrm{~K}$ proteins. This result was expected, as there is no detectable interaction between the $\mathrm{E} 1 \mathrm{~B} 19 \mathrm{~K}$ and $\mathrm{Bcl}-2$ proteins when assayed in the yeast two-hybrid system (data not shown). However, when Bcl-2 and Bax were cotranslated, immunoprecipitation with a $\mathrm{Bcl}-2$-specific antibody coprecipitated Bax (Fig. 3A). Bax migrated with a slightly higher molecular mass $(22.5 \mathrm{kD}$ rather than $21 \mathrm{kD})$ because of the Myc epitope tag. Immunoprecipitation with a polyclonal antibody specific for the E1B $19 \mathrm{~K}$ protein specifically precipitated the E1B $19 \mathrm{~K}$ protein and not Bax or Bcl-2 (Fig. 3A). The E1B 19K and Bcl-2 proteins also did not coimmunoprecipitate with the E1B 19K-specific antibody, as was the case with the Bcl-2-specific antibody (Fig. 3A). When the E1B $19 \mathrm{~K}$ and Bax proteins were cotranslated, however, both E1B $19 \mathrm{~K}$ and Bax were precipitated (Fig. 3A). In the converse experiment, cotrans- 


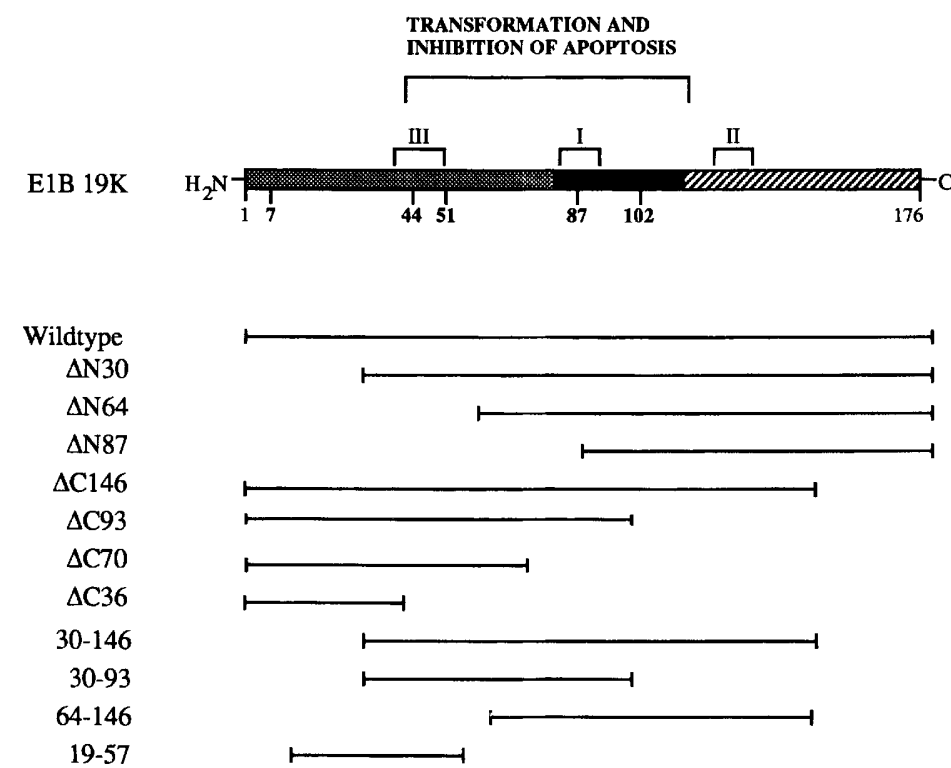

$\begin{array}{cc}\text { Interaction } & \begin{array}{c}\text { Interaction } \\ \text { with Bax }\end{array} \\ \text { exon3 } & \text { with Bax }\end{array}$

$\Delta$ ildtype
$\Delta \mathrm{N} 30$
$\Delta \mathrm{N} 64$
$\Delta \mathrm{N} 87$
$\Delta \mathrm{C} 146$
$\Delta \mathrm{C} 93$
$\Delta \mathrm{C} 70$
$\Delta \mathrm{C} 36$
$30-146$
$30-93$
$64-146$
$19-57$

Figure 2. Mapping of the minimal region of the E1B 19K protein required for interaction with Bp3-Ex3 (amino acids 50-78 of hBax) and rBax. A schematic representation of the 176 amino acids of wild-type E1B 19K protein highlights some of its structural features. Among the various adenovirus serotypes, amino acids $1-81$ (stippled area) share $52 \%$ identity, amino acids $82-113$ (solid area) is the most conserved region with $63 \%$ identity and amino acids $114-176$ (hatched area) is least conserved with $37 \%$ identity (Chiou et al. 1994b). The region between amino acids 44 and 113 has been determined previously as being required for transformation and inhibition of apoptosis and is indicated (White et al. 1992; Chiou et al. 1994b). Boxed regions I, II, and III define the Bcl-2 homology regions BHI, $\mathrm{BH} 2$, and $\mathrm{BH} 3$, respectively. Locations of the point mutants of $\mathrm{E} 1 \mathrm{~B} 19 \mathrm{~K}$ tested in the two-hybrid system $(\mathrm{pm} 7, \mathrm{pm} 44, \mathrm{pm} 51, \mathrm{pm} 87$, and $\mathrm{pm} 102)$ are in boldface type. Deletion mutants of the E1B $19 \mathrm{~K}$ protein were generated from the amino-terminal direction $(\Delta \mathrm{N} 30, \Delta \mathrm{N} 64$, $\Delta \mathrm{N} 87)$, the carboxy-terminal direction $(\Delta \mathrm{C} 146, \Delta \mathrm{C} 93, \Delta \mathrm{C} 70, \Delta \mathrm{C} 36)$, and both directions $(30-146,30-93,64-146,19-57)$ and tested for interaction with either full-length $\mathrm{rBax}$ or Bp3-Ex3 in the two-hybrid system. Positive interactions were scored by the number of colonies obtained on plates without in comparison to plates containing histidine and by the intensity of blue color in a $\beta$-galactosidase assay. $1+++\mid$ Strong interaction; $(+)$ weak interaction; $|-|$ no interaction.

lation of E1B $19 \mathrm{~K}$ and Bax, followed by immunoprecipitation with an anti-Bax antibody, also coimmunoprecipitated E1B 19K with Bax (Fig. 3A). Bax also coimmunoprecipitated with Bcl-2, as expected (Fig. 3A). These results indicate that the E1B $19 \mathrm{~K}$ protein can specifically interact with Bax in vitro, which serves as an independent confirmation of results obtained from the yeast two-hybrid system.

To further substantiate the in vitro interactions observed, a glutathione $S$-transferase (GST) fusion protein system was employed. GST-19K, a GST fusion of E1B 19K GST-pm51, a GST fusion of a E1B 19K mutant within the $\mathrm{BH} 3$ region defective for Bax interaction in yeast, and GST alone were immobilized onto glutathione-Sepharose beads, purified, and used to confirm the interaction between the E1B $19 \mathrm{~K}$ and Bax proteins (Fig. 3B). Equal amounts of GST-fusion proteins $(3 \mu \mathrm{g})$ were incubated with either Bax or Bcl-2 proteins translated in vitro (Fig. $3 \mathrm{C}$ ). In vitro-translated Bax bound to the GST$19 \mathrm{~K}$ fusion protein but did not bind to either GST alone or the E1B 19K point mutant GST-pm51 (Fig. 3C). However, in vitro-translated Bcl-2 did not bind to GST-19K, GST-pm51, or GST alone (Fig. 3C). Thus, Bax specifically interacted with the E1B $19 \mathrm{~K}$ protein in this assay, and complex formation with Bax was abrogated by a single amino acid substitution in the region identical to that in the two-hybrid assays required for 19K/Bax interaction. To verify the protein band as Bax, a portion of the in vitro-translated protein mix was immunoprecipitated with a monoclonal antibody specific for the Myc epitope tag on $\mathrm{rBax}$, as opposed to an E1B $55 \mathrm{~K}$ antibody (13D2) (Fig. 3C). In vitro-translated Bcl-2 was also immunoprecipitated by using a Bcl-2 polyclonal antibody as opposed to a nonspecific antibody (Fig. 3C). In each case, in vitro-translated protein was immunoprecipitated with its corresponding antibody as opposed to a nonspecific antibody.

The association of the E1B $19 \mathrm{~K}$ and Bax proteins in the yeast two-hybrid system and the ability of the E1B 19K and Bax proteins to complex in vitro suggested that they may interact in mammalian cells. Detection of proteinprotein complexes has been successful previously through coimmunoprecipitation of cellular proteins from cell lysates prepared under mild lysis conditions. The E1B 19K protein, however, is insoluble when expressed in mammalian cells and generally requires harsh detergent conditions to be extracted from cells for immunoprecipitation (White et al. 1984; White and Cipriani 1990). These conditions, however, are usually not suitable for protein interactions to remain intact. Conditions used to coimmunoprecipitate Bax complexed to Bcl-2 (Oltvai et al. 1993), for example, immunoprecipi- 
Han et al.
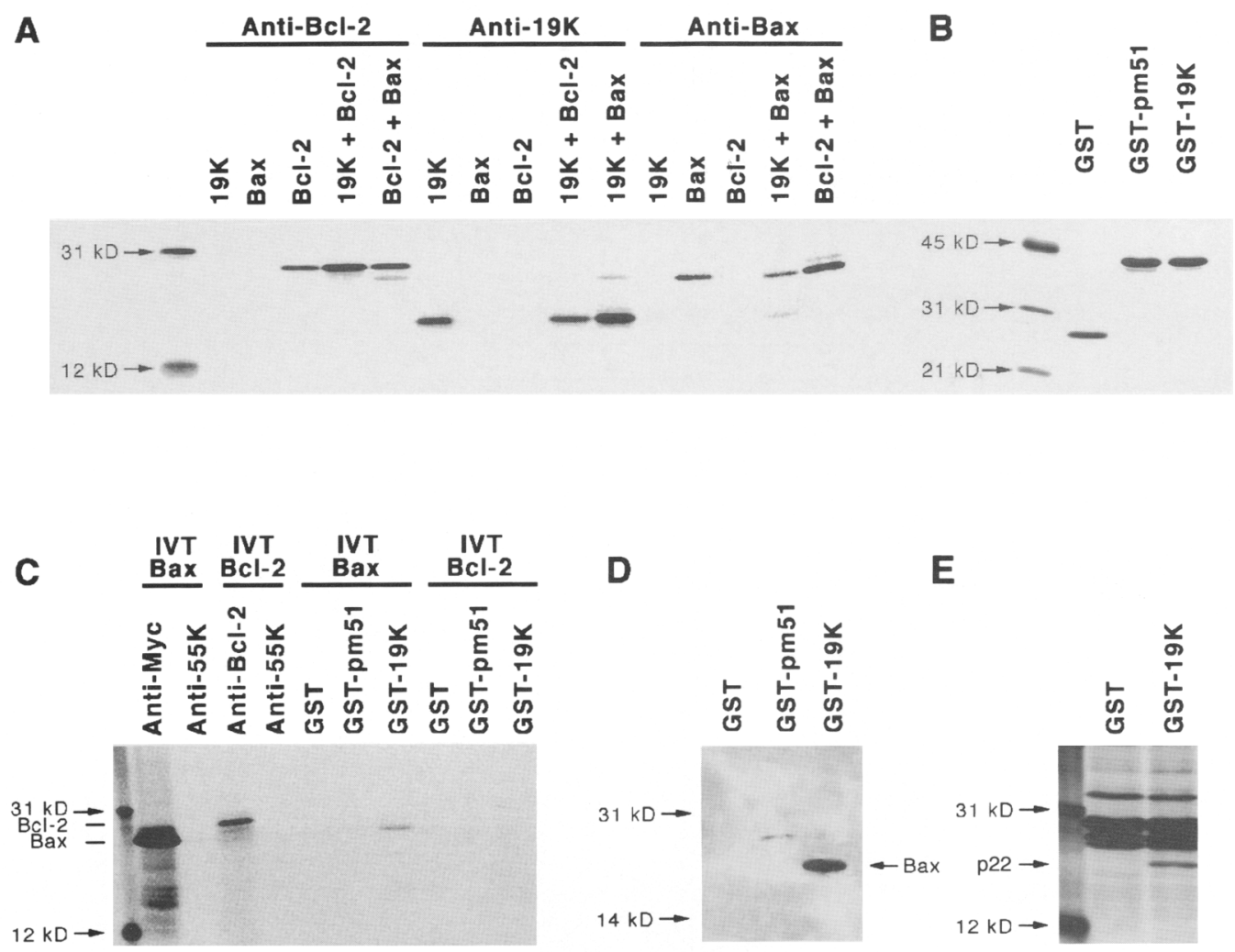

Figure 3. Association of the $\mathrm{E} 1 \mathrm{~B} 19 \mathrm{~K}$ protein with $\mathrm{rBax}$ in vitro and in cell lysates. $(A)$ Coimmunoprecipitation of in vitro-translated $\mathrm{rBax}$ and E1B $19 \mathrm{~K}$ proteins. Immunoprecipitation was carried out with in vitro-synthesized and $\left[{ }^{35} \mathrm{~S}\right]$ methionine-labeled Bcl-2, E1B $19 \mathrm{~K}$, and Bax, in the specific combinations indicated, with antibodies directed against Bcl-2, Bax, and E1B 19K proteins. $(B)$ Production of GST-fusion proteins. GST-19K, GST-pm51, and GST alone were produced in Escherichia coli and purified on glutathioneSepharose beads, and the levels and purity of the GST fusions were evaluated by SDS-PAGE. Equal concentrations (3 $\mu \mathrm{g})$ of GST-19K, GST-pm51, and GST were used for the binding experiments in $C$ and $D$. $|C|$ In vitro-translated rBax associates with the GST-19K fusion protein. GST-fusion proteins were immobilized onto glutathione-Sepharose beads and incubated with in vitro-translated $\mathrm{rBax}$ or hBcl-2 in the presence of NETN buffer as indicated. Immunoprecipitation of in vitro-translated $\mathrm{rBax}(\mathrm{Myc} \mathrm{Ab})$ and $\mathrm{hBcl}-2(\mathrm{Bcl}-2 \mathrm{Ab})$ is shown. An antibody directed against the E1B $55 \mathrm{~K}$ protein (13D2) was used as a control for nonspecific precipitation. (D) Interaction of the cellular rBax protein with the GST-19K fusion protein. Cold cell lysates prepared from the Anl cell line were incubated with GST-fusion proteins GST-19K and GST-pm51 immobilized on glutathione beads. Proteins were analyzed by SDS-PAGE and Western blotting with an anti-Bax polyclonal antibody. $|E|$ Interaction of $\left[{ }^{3.5} S \mid\right.$ methionine-labeled BRK cell proteins with GST and GST--19K. Labeled cell extracts of the Anl cell line were indubated with GST or GST-19K, and the bound products were alanized by SDS-PAGE. A protein with a molecular mass of $\sim 22 \mathrm{kD}(\mathrm{p} 22)$ was the only GST-19K-specific band. p22 comigrated with Bax $(D)$.

tate $<1 \%$ of the $19 \mathrm{~K}$ protein from cell lysates /data not shown). To circumvent this problem, the E1B $19 \mathrm{~K}$ protein was immobilized onto glutathione-Sepharose beads as a GST-fusion protein (GST-19K) and then incubated with unlabeled lysates prepared from the E1A plus tsp53(vall35)-transformed BRK cell line Anl (Debbas and White 1993), under conditions where Bax was expressed (see Western blot in Fig. 6, below). Cell lysates were incubated with GST alone, GST-pm51, or the GST-19K fusion proteins bound to beads in a GST pulldown assay. Bound cellular proteins were subjected to immunoblotting analysis by probing with an anti-Bax polyclonal antibody. rBax was specifically detected bound to the GST-19K fusion protein but not to either GST alone or the E1B 19K mutant GST-pm51 (Fig. 3D).

To further evaluate the specificity of the Bax interac- tion with GST-19K protein, a $\left[{ }^{35} \mathrm{~S}\right]$ methionine-labeled BRK cell extract was incubated with either GST or GST$19 \mathrm{~K}$, and the number of bound cellular proteins was examined. There was a single specific $\left[{ }^{35} S\right]$ methionine-labeled band migrating with an approximate molecular mass of $22 \mathrm{kD}(\mathrm{p} 22)$ that bound to GST-19K but not GST (Fig. 3E). p22 migrated in the expected position of Bax (see Fig. 3D), indicating that the interaction of cellular proteins with GST-19K was highly selective and that Bax interacts with high specificity. These results demonstrate that the E1B $19 \mathrm{~K}$ protein can associate with Bax specifically in the context of a whole cell extract, suggesting that an in vivo interaction between the two proteins is probable and supports the findings obtained from the two-hybrid system and the in vitro coassociation of E1B 19K and Bax. 
E1B 19K-Bax functional interaction
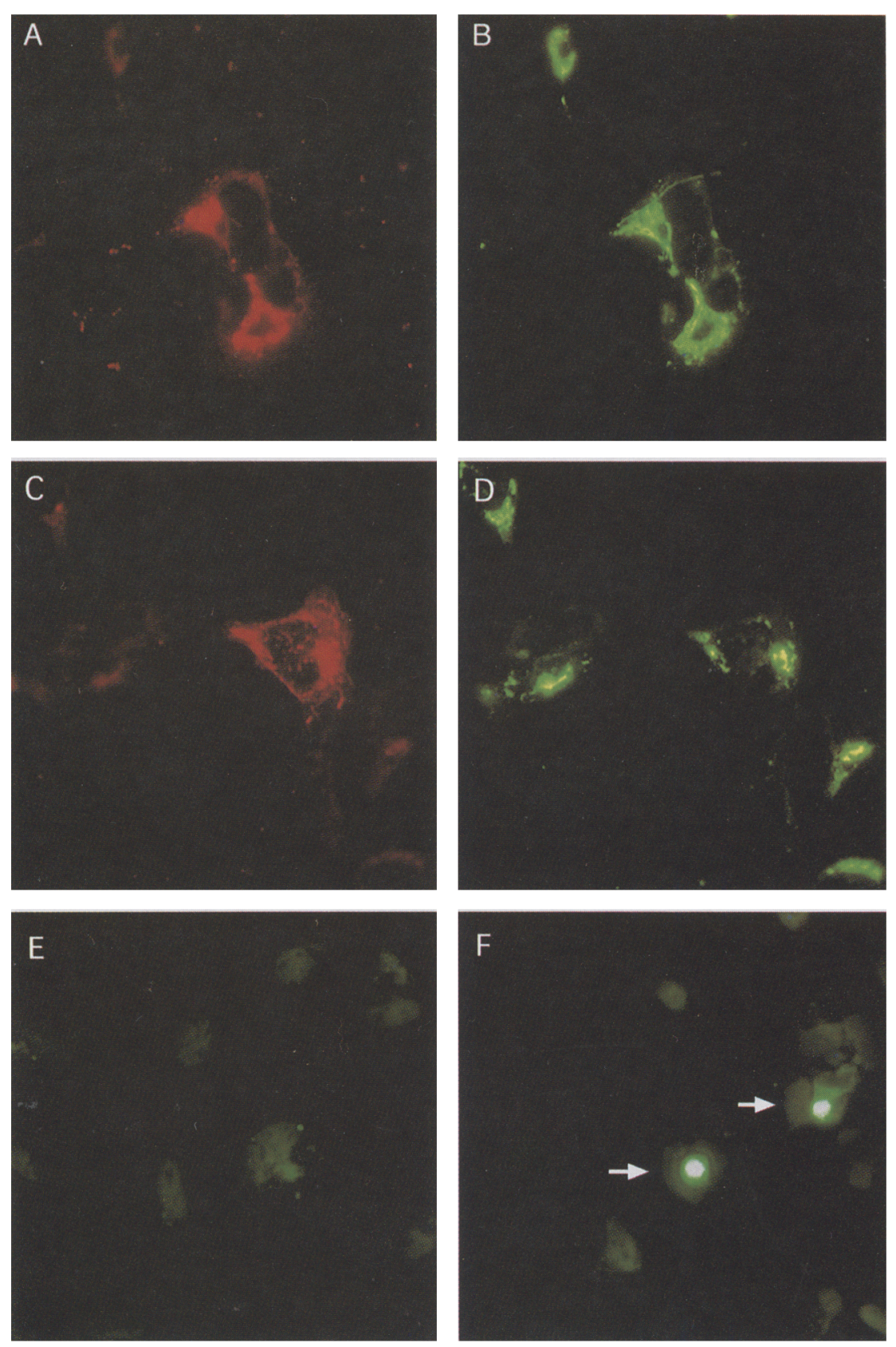

Figure 4. ElB $19 \mathrm{~K}$ and Bax display overlapping intracellular localization. The 19K1 cell line was transfected with pCEP4Myc-rBax expression vector and processed for double-label indirect immunofluorescence $48 \mathrm{hr}$ post-transfection. The cells were stained with a monoclonal antibody directed against the Myc epitope tag on $\operatorname{rBax}(A, C)$ and a polyclonal antibody directed against the E1B $19 \mathrm{~K}$ protein $(B, D)$. $(E, F\rangle$ Induction of DNA fragmentation by transient Bax expression in BRK cells. The $\mathrm{TdT}$ assay to detect DNA fragmentation in situ was used in vector control $(E)$ or CMVBax-transfected $(F)$ 19K1 cells. Labeling with TdT is indicative of cells undergoing apoptotic cell death (arrows in F). Original magnification, $600 \times$.
E1B $19 \mathrm{~K}$ and Bax proteins have overlapping intracellular localization

The E1B $19 \mathrm{~K}$ protein is found associated with the cytoplasmic and nuclear membranes and with the insoluble nuclear lamina (White et al. 1984; White and Cipriani 1990). To determine whether the Bax and E1B 19K proteins reside in the same subcellular compartment, double-label indirect immunofluorescence studies were performed. Transient Bax expression induced apoptosis in BRK cells that did not express the E1B $19 \mathrm{~K}$ protein (data not shown); therefore, the cytomegalovirus (CMV) Myctagged rBax expression vector (pCEP4-Myc-rBax) was electroporated into the $19 \mathrm{Kl}$ cell line, which is an E1A plus tsp53(val135)-transformed BRK cell line that stably expresses the E1B 19K protein (Debbas and White 1993). Cell death following Bax expression was delayed sufficiently in the $19 \mathrm{Kl}$ cell line to permit visualization of Bax and 19K localization. The pCMV-rBax (pCEP4Myc-rBax)-transfected 19K1 cells were fixed 48 hr posttransfection and stained with a monoclonal antibody specific for the Myc epitope on $\mathrm{rBax}$ and a polyclonal antibody directed against the E1B $19 \mathrm{~K}$ protein. As reported previously (White et al. 1984; White and Cipriani 1989; White and Cipriani 1990), the E1B 19K protein was detected primarily at the nuclear envelope, and cytoplasmic membranes were typified by bright punctate cytoplasmic staining (Fig $4 \mathrm{~B}$ and D). Half of the Bax positive 
cells displayed colocalization of the two proteins typical of cytoplasmic membranes (Fig. 4A, B). The $19 \mathrm{~K}$ protein is membrane and cytoskeletal bound (White et al. 1984), and $\mathrm{Bax} \alpha$ possess a transmembrane domain and would be expected to be membrane bound also (Oltvai et al. 1993). The remaining cells had an overlapping staining pattern with the E1B $19 \mathrm{~K}$ protein (Fig. $4 \mathrm{C}, \mathrm{D}$ ). These data suggested that a substantial fraction of Bax protein in vivo may reside in the same intracellular compartment as the E1B 19K protein.

Bax expression was eventually lethal in $19 \mathrm{~K} 1$ cells, as evidenced by pronounced morphological changes and the loss of cell viability (see below) that accumulated with time following transfection and Bax protein expression. To address whether the cell death induced by transient Bax expression resembled apoptosis, a terminal deoxynucleotidyl transferase (TdT) assay (Gavrieli et al. 1992) was performed to detect the presence of fragmented DNA. Vector control-transfected cells were viable and had a low incidence of TdT-positive cells (Fig. 4E). The CMV-Bax-transfected cells, however, displayed a frequency of TdT-positive cells with condensed nuclei severalfold higher (Fig. 4F), suggesting that the cell death induced by Bax occurred by an apoptotic process.

Bax antagonizes apoptosis inhibition by the E1B $19 \mathrm{~K}$ protein

Because $\mathrm{rBax}$ interacted with the $\mathrm{E} 1 \mathrm{~B} 19 \mathrm{~K}$ protein in yeast and in vitro, we tested whether rBax could antagonize the antiapoptotic function of the E1B $19 \mathrm{~K}$ protein in BRK cells. The E1A plus tsp53(vall35)-transformed BRK cell line Anl is transformed at the restrictive temperature but undergoes apoptosis at the permissive temperature (Debbas and White 1993). Transient ElB 19K expression, however, protects the An1 cell line from p53mediated apoptosis at the permissive temperature as measured by an increase in cell survival greater than fivefold at $60 \mathrm{hr}$ post-transfection (Fig. 5). To determine whether Bax can reverse this E1B 19K protection against Bax-mediated apoptosis, the Bax expression vector pCEP4-Myc-rBax was transfected in increasing amounts with respect to a constant level of the E1B 19K expression vector pcDNA3-19K. The Anl cell line was also transfected with the rBax expression vector alone as a control. The transfected cells were incubated at the restrictive temperature to permit Bax and ElB 19K protein expression for $60 \mathrm{hr}$ and were then shifted to the permissive temperature for $60 \mathrm{hr}$. The viable cell number was assessed by trypan blue exclusion.

In the absence of $19 \mathrm{~K}$ expression, viability was reduced to $5 \%$ because of massive apoptosis at the permissive temperature (Fig. 5). Transfection of the rBax expression vector did not increase apoptosis measurably under these conditions of $95 \%$ cell death (Fig. 5). Cotransfection of increasing concentrations of the $\mathrm{rBax}$ expression vector with the E1B $19 \mathrm{~K}$ expression vector, however, greatly diminished survival conferred by E1B 19K expression (Fig. 5). When the rBax vector DNA was transfected at a

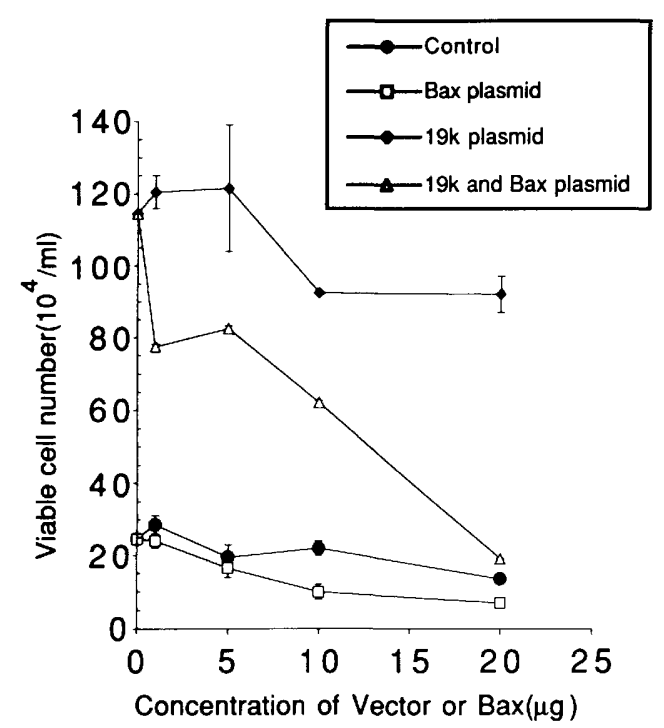

Figure 5. Bax antagonizes the antiapoptotic function of the E1B 19K protein. Increasing concentrations $(1,5,10$, and $20 \mu \mathrm{g})$ of the rBax expression vector DNA (pCEP4-Myc-rBax) or the control empty vector DNA were cotransfected into the Anl cell line with a fixed concentration $(10 \mu \mathrm{g})$ of pcDNA3-19K DNA or the control vector DNA. The transfected Anl cell lines were incubated at $38.5^{\circ} \mathrm{C}$ for $60 \mathrm{hr}$ and then at $32^{\circ} \mathrm{C}$ for $60 \mathrm{hr}$. Viable cell number was assessed by trypan blue exclusion.

$2: 1$ ratio to $19 \mathrm{~K}$ vector DNA, viability was reduced to the level of the control. Reduction of $\mathrm{rBax}$ vector levels relative to E1B $19 \mathrm{~K}$ vector levels proportionally increased the level of protection from cell death by the E1B 19K protein (Fig. 5). Therefore, rBax protein antagonized the antiapoptotic function of the E1B $19 \mathrm{~K}$ protein, suggesting an in vivo functional interaction between these two apoptosis regulators.

\section{Wild-type p53 induces bax mRNA and protein expression}

Recent evidence indicates that bax is a p53-inducible gene and that bax expression parallels p53-mediated apoptosis in certain cell types (Miyashita et al. 1994; Miyashita and Reed 1995). Therefore, we wanted to determine whether bax gene expression was up-regulated in BRK cell lines that succumb to p53-mediated apoptosis at the permissive temperature. We have demonstrated recently that ElA-induced apoptosis in BRK cells requires a transcriptionally functional p53 (Sabbatini et al. 1995b). The BRK cell line 22-23val135A, which expresses E1A and a transcriptionally defective tsp53/2223 vall35), was used as a negative control for p53-mediated trans-activation at the permissive temperature. tsp53(22-23val135) is transcriptionally defective because of a double mutation within the trans-activation domain of p53 (Lin et al. 1994; Sabbatini et al. 1995b). Accordingly, this cell line does not succumb to p53-mediated apoptosis at the permissive temperature (Sabbatini et al. 1995b|. Cytoplasmic RNA was extracted at increasing 
time points at the permissive temperature and then subjected to Northern blot analysis.

Results indicate that rbax mRNA levels increased three- to fivefold in the Anla and Anlb cell lines [two E1A plus tsp53(val135)-transformed BRK cell lines] within $4 \mathrm{hr}$ of incubation at the permissive temperature (Fig. 6A). rbax mRNA levels remained at induced levels in the Anla cell line after $9 \mathrm{hr}$ of incubation at the permissive temperature but appeared to decrease in the Anlb cell line at this time point (Fig. 6A). However, this sudden decrease in rbax mRNA levels in the Anlb cell line is likely attributable to lower overall levels of mRNA because of cell death, as it was paralleled by a corresponding decrease in the levels of actin mRNA /Fig. 6A). Expression of bax in the $19 \mathrm{Kl}$ cell line, which undergoes p53-mediated growth arrest at the permissive temperature (Debbas and White 1993; Lin et al. 1995; Sabbatini et al. 1995a), was also up-regulated three- to fivefold at the permissive temperature (Fig. 6A). The $19 \mathrm{~K} 1$ cell line is protected from apoptosis, and any reduction in intact mRNA attributable to cell death is therefore prevented, which may account for the prominent rbax mRNA induction. In contrast, bax mRNA levels were barely detectable in the 22-23val.135A cell line at either the restrictive or permissive temperature, consistent with the fact that tsp53(22-23val135) is transcriptionally defective at both temperatures (Sabbatini et al. 1995b). Moreover, the patterns of expression of the p53inducible gene $p 21 /$ Waf-1/Cip-1 and rbax in all cell lines were identical (Fig. 6A). These results are consistent with previous findings demonstrating that $\mathrm{p} 53$-mediated trans-activation remains intact in both the Anla and $19 \mathrm{~K} 1$ cell lines but is dramatically impaired in the 22 23val135A cell line (Sabbatini et al. 1995b). Thus, apoptosis appears to require a transcriptionally competent p53, and bax mRNA induction parallels p21/WAF-1/ Cip-1 mRNA induction and correlates with apoptosis.

Western blot analysis indicates that $\mathrm{rBax}$ protein levels increased dramatically and progressively in both the Anla and Anlb cell lines following incubation at the permissive temperature (Fig. 6B). Bax protein levels also increased progressively in both the $19 \mathrm{~K} 1$ and $4 \mathrm{~B}$ cell lines at the permissive temperature (Fig. 6B). The apparent slight difference in the kinetics of Bax accumulation in $19 \mathrm{Kl}$ and $4 \mathrm{~B}$ compared to the Anl cell line was attributable to variations in blotting conditions, as it was not observed when An1,19K1, and 4B were analyzed on the same blot (data not shown). Interestingly, Bax protein levels remained high in the $19 \mathrm{Kl}$ and Bcl-2 cell lines through $96 \mathrm{hr}$ at the permissive temperature, at which point cells have undergone p53-mediated growth arrest (Fig. 6B). E1B 19K protein levels also increased dramatically (Fig. 6B). There was no increase in $19 \mathrm{~K} \mathrm{mRNA} \mathrm{lev-}$ els, and in pulse-chase experiments, the half-life of the ElB $19 \mathrm{~K}$ protein was increased from $4 \mathrm{hr}$ to $>12 \mathrm{hr}$ (data not shown). Although E1B $19 \mathrm{~K}$ protein accumulation was apparently the result of an increase in the stability of the protein, whether this was caused by the presence of rBax has not yet been determined. As predicted from the Northern blot analysis, rBax protein levels were barely detectable in the 22-23val135A cell line at either the restrictive or permissive temperature (Fig. 6B). In addition, the corresponding patterns of expression of $\mathrm{rBax}$ and $\mathrm{p} 21 / \mathrm{Waf}-1 / \mathrm{Cip}-1$ protein in each cell line were identical (Fig. 6B).

These results indicate that Bax and $\mathrm{p} 21 / \mathrm{Waf}-1 / \mathrm{Cip}-1$ are equally up-regulated in BRK cell lines that succumb to either p53-mediated apoptosis or growth arrest at the permissive temperature. In addition, they are consistent with the fact that the E1B $19 \mathrm{~K}$ and $\mathrm{Bcl}-2$ proteins function downstream of $\mathrm{p} 53$-mediated trans-activation to overcome p53-mediated apoptosis.

\section{Bax is sufficient for apoptosis and acts downstream of $p 53$}

p53 can activate the transcription of genes involved in growth arrest, such as $p 21 / W a f-1 / C i p-1$, and in apoptosis, such as bax. In BRK cells the induction of apoptosis requires a transcriptionally competent p53 (Sabbatini et al. 1995b). bax induction by p53 may be responsible for apoptosis, or bax may be only one gene product of many that is required for activation of the death pathway by p53. To test this hypothesis, $\mathrm{rBax}$ was transfected into the An1 cell line at the restrictive temperature where p53 was constitutively in the mutant conformation to determine whether bax expression alone was capable of inducing cell death.

Anl was transfected at $38.5^{\circ} \mathrm{C}$ (restrictive temperature) with the rBax expression vector (pCEP4-Myc-rBax) containing a hygromycin resistance marker or a vector control lacking the rBax cDNA and placed under drug selection. After 21 days, the number of hygromycin resistant colonies was evaluated by Giemsa staining. As seen in Fig. 7, there was a sixfold reduction in the number of colonies in the rBax-transfected cells compared with the control. Transient Bax expression induced cell death that resembled apoptosis (data not shown), suggesting that Bax was sufficient for the induction of apoptosis in the presence of mutant p53. Thus, Bax alone was capable of inducing apoptosis, which is consistent with it functioning downstream of $\mathrm{p} 53$.

\section{Discussion}

The adenovirus E1B 19K protein plays an important role in inhibiting apoptosis during the productive infection of human cells and during the transformation process of primary rodent cells. Without ElB 19K function, virus production is compromised because of premature death of the host cell (White 1994; White and Gooding 1994) and transformation by ElA is aborted (Rao et al. 1992; White et al. 1992). Early evidence suggested that the E1B $19 \mathrm{~K}$ protein functioned as an apoptosis inhibitor and possessed both structural and functional homology to Bcl-2 (White et al. 1991; Rao et al. 1992; White et al. 1992). The capacity of the E1B $19 \mathrm{~K}$ protein to interact and display functional antagonism with Bax further supports the suggestion that it is the adenovirus Bcl-2 homolog. Other DNA viruses harbor open reading frames with ho- 
Han et al.

Figure 6. Up-regulation of bax and $p 21 /$ Waf-1/ Cip-1 mRNA and protein levels in BRK cell lines by p53. (A) Northern blots of RNA isolated from the Anla, Anlb, 22-23val135A, and 19K1 cell lines at the restrictive $(0 \mathrm{hr})$ and permissive (4 and $9 \mathrm{hr}$ ) temperatures were hybridized with probes corresponding to $r b a x|t o p|$, murine $p 21 /$ Waf-1/Cip-1-1 (middle), and murine $\beta$-actin (bottom). (B) Western blot analysis of $\mathrm{rBax}$ and p21/Waf-1/Cip-1 expression in the Anla, Anlb, 22-23vall35A, 19K1, and 4B cell lines at the restrictive and permissive temperatures. Total cell extracts were prepared from the Anla, Anlb, and 22-23val135A cell lines at the restrictive temperature $(0 \mathrm{hr})$ and after incubation for 6,12 , and $24 \mathrm{hr}$ at the permissive temperature. Extracts were prepared from the $19 \mathrm{Kl}$ and $4 \mathrm{~B}$ cell lines at the restrictive temperature $(0 \mathrm{hr})$ and after incubation for $6,12,24,48$, and $96 \mathrm{hr}$ at the permissive temperature. Western blots were probed with antibodies specific for $\operatorname{Bax}(\mathrm{N}$ 20), p21/Waf-1/Cip-1-1, and actin. Blots containing extracts from the $19 \mathrm{Kl}$ and $4 \mathrm{~B}$ cell lines were also probed with antibodies directed against the E1B 19K (2F3) and Bcl-2 (1632-15) proteins, respectively.
A

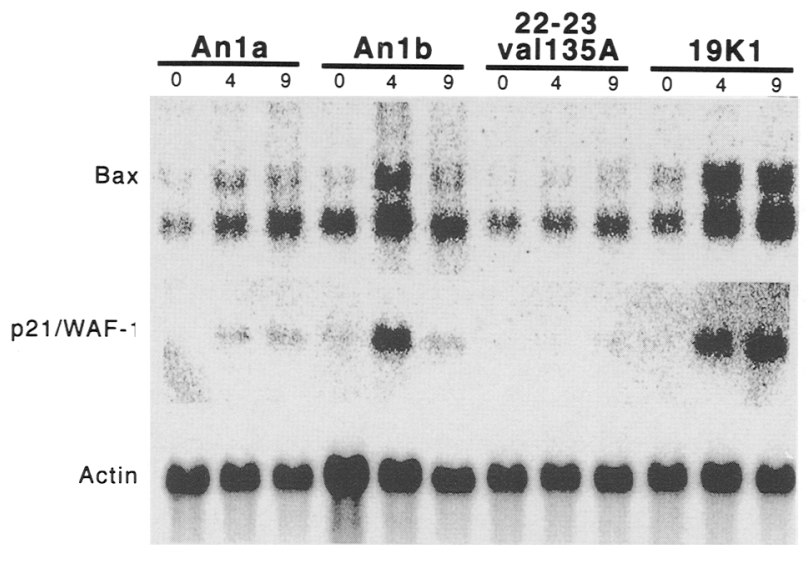

B
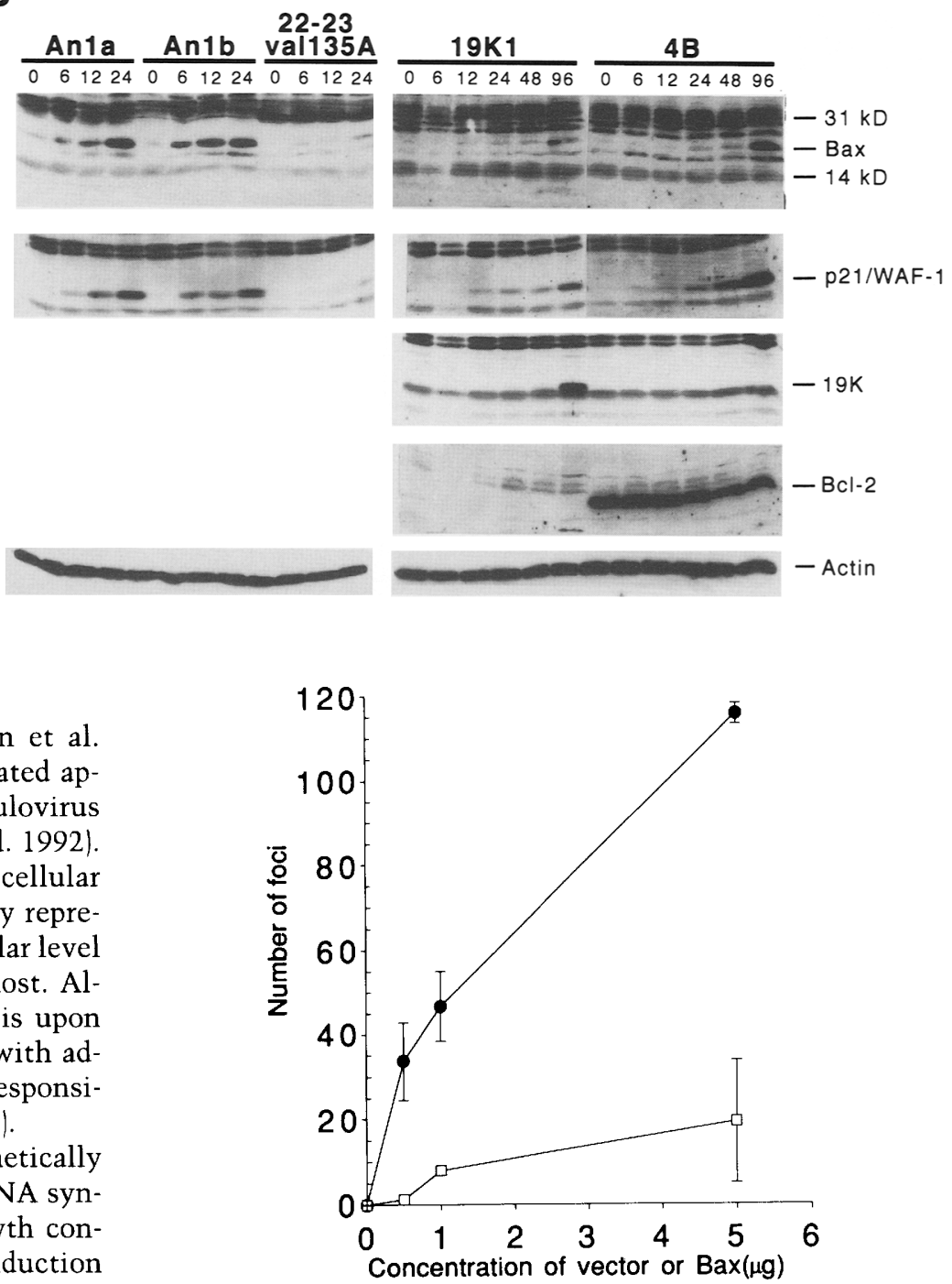

Figure 7. Bax is sufficient for induction of apoptosis and acts downstream of $\mathrm{p} 53$. The E1A plus tsp53-transformed BRK cell line AN1 was transfected with $0.5,1.0$, and $5.0 \mu \mathrm{g}$ of linerized CMV-Bax plasmid (pCEP4-Myc-rBax) or control vector DNA $(\square)$ by electroporation. After 21 days post-transfection at $38.5^{\circ} \mathrm{C}$ with selection for hygromycin resistance (O), the number of foci number was determined following Giemsa staining. 
lowing E1A expression (Lowe and Ruley 1993; Chiou et al. 1994a), which mimics the p53 response to DNA damage (Maltzman and Czyzyk 1984; Kastan et al. 1991, 1992; Kuerbitz et al. 1992), supporting a role for p53 as a surveillance factor to induce growth arrest or apoptosis of abnormal, damaged, or infected cells. p53 can induce growth arrest or apoptosis in different physiological settings. Bcl-2 and E1B $19 \mathrm{~K}$ expression can specifically block the induction of apoptosis by $\mathrm{p} 53$, but the growth arrest function is intact (Debbas and White 1993; Chiou et al. 1994a; Lin et al. 1995; Sabbatini et al. 1995a). This suggests that growth arrest and apoptosis are distinct activities of p53 and that Bcl-2 levels may be a determining factor in regulating the physiological outcome following p53 induction.

p53 is a transcription factor that activates the transcription of a number of cellular genes, one of which is the p21/Waf-1/Cip-1 cell cycle-dependent kinase inhibitor (El-Deiry et al. 1993; Harper et al. 1993; Xiong et al. 1993; Noda et al. 1994). p21 expression can induce cell cycle arrest, suggesting that it is one means by which p53 can arrest cell growth. The role of the transcriptional activity of p53 in regulating apoptosis has been less clear and may be cell type specific (Caelles et al. 1994; Haupt et al. 1995; Sabbatini et al. 1995b). Transcriptional induction of the bax gene by p53, for example, has been associated with apoptosis in some settings (Miyashita et al. 1994; Miyashita and Reed 1995) but not in others (Canman et al. 1995). In the ElA plus p53(val135) BRK transformants that we have generated, however, p53 requires a functionally competent trans-activation domain for the induction of apoptosis (Sabbatini et al. 1995b). Thus, the activity of p53 as a transcription factor is likely required for induction of apoptosis in BRK cells. p53 could potentially activate the transcription of death genes such as bax or repress the transcription of survival genes such as $b c l-2$ to promote cell death. Because the E1B 19K and Bcl-2 proteins both associate with Bax, they could potentially prevent any adverse effect of Bax on cell viability following p53-promoted Bax accumulation (Fig 8). bax mRNA and protein levels were induced specifically and dramatically upon conformational change of p53 from the mutant to the wild-type form, and a transcriptionally defective p53 was incapable of display-

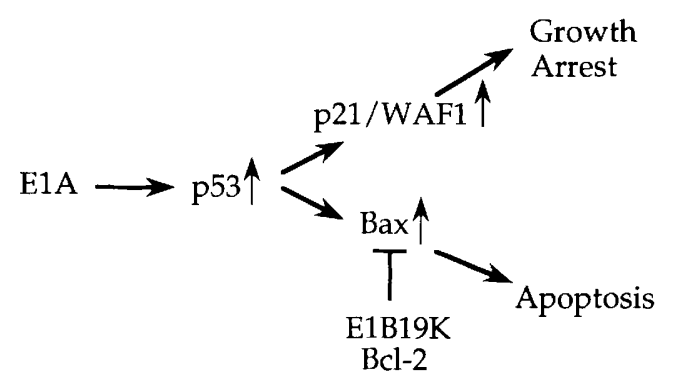

Figure 8. Model for separation of p53-mediated apoptosis and growth arrest functions by interaction of the E1B $19 \mathrm{~K}$ and Bcl-2 proteins with the Bax protein. ing this activity, providing strong evidence that bax is either directly or indirectly regulated by p 53 at the transcriptional level.

E1B $19 \mathrm{~K}$ and Bcl-2 expression, although sufficient to block cell death, had no impact on bax message or protein accumulation, suggesting that they act downstream of bax induction by p53 (Fig. 8). Furthermore, as the E1B $19 \mathrm{~K}$ - and Bcl-2-expressing cells do not die, Bax induction by 553 can be uncoupled from cell death, ruling out the possibility that Bax induction is merely a symptom of cells undergoing the death process. E1B 19K protein levels increase following Bax induction. There was an increase in the half-life of the $19 \mathrm{~K}$ protein but no change in the level of $19 \mathrm{~K}$ message, suggesting a post-transcriptional mechanism of protein accumulation. Perhaps $19 \mathrm{~K}$ stabilization is prompted by the sudden increase in and interaction with Bax.

Bax has been demonstrated to associate with Bcl-2 and antagonize the ability of Bcl-2 to block apoptosis (Oltvai et al. 1993). In functional assays, Bax expression also antagonized the ability of the E1B $19 \mathrm{~K}$ protein to block apoptosis. E1B 19K and Bcl-2 expression in BRK cells has no measurable effect on cell viability or growth unless p53 is converted to the wild-type form. Only under these circumstances when Bax levels, which are virtually undetectable in the presence of mutant $\mathrm{p} 53$, are increased by the presence of wild-type p53, is any functional activity of either E1B $19 \mathrm{~K}$ or Bcl-2 apparent. It is possible that Bax is ineffective at inducing apoptosis as long as $\mathrm{Bcl}-2$ and $\mathrm{E} 1 \mathrm{~B} 19 \mathrm{~K}$ proteins are expressed in relative excess of Bax and thus they may serve to sequester Bax activity to preserve cell viability.

Bax expression induced apoptosis in cells that constitutively expressed mutant p53, suggesting that Bax alone was sufficient to induce cell death and that it acts downstream of $\mathrm{p} 53$. Whether bax is the only death gene transcriptionally activated by $\mathrm{p} 53$, or one of many that function redundantly, is not yet known. When expressed in other cell types, however, Bax expression is not lethal and only induces apoptosis upon receipt of a death signal such as factor withdrawal (Oltvai et al. 1993). A death signal is apparently necessary in some cell types and may depend on the levels of expression of endogenous Bcl-2like proteins. The induction of apoptosis by Bax in BRK cells in the presence of mutant p53 may be because the level of expression of endogenous Bcl-2-like proteins is low (both Bcl-2 and Bcl-x protein levels are barely detectable in BRK cell lines; data not shown). Alternatively, the E1A expressed in BRK cells may provide a constitutive death signal that only requires wild-type p53, and thereby Bax expression, for implementation of the death program.

The relationship between the cell cycle and apoptosis has been suggested by a number of experiments, but the molecular basis of the relationship has been unclear. Deregulation of cell growth by E1A and c-Myc expression can stimulate p53 accumulation and p53-dependent apoptosis (Askew et al. 1991; White et al. 1991; Evan et al. 1992; Amati et al. 1993; Hermeking and Eick 1994). Whether apoptosis is the result of conflicting growth sig- 
nals generated by simultaneous opposing positive and negative forces governing cell cycle progression, or some other cause, is not known. Apoptosis has been reported to occur preferentially at the $G_{1} / S$ transition and $S$ in some cases (Yonish-Rouach et al. 1993), in any phase of the cell cycle in others, or to either precede or follow growth arrest. Our data suggest that p53 simultaneously activates both the growth arrest and apoptosis pathways through the transcriptional activation of $p 21 /$ Waf $-1 /$ Cip-1 and bax genes, respectively (Fig. 8). In situations of limiting amounts of $\mathrm{Bcl}-2$ or $\mathrm{E} 1 \mathrm{~B} 19 \mathrm{~K}$ proteins, the apoptotic pathway will be dominant over the growth arrest pathway. In Bcl-2 or E1B $19 \mathrm{~K}$ protein excess /and Bax sequestration\}, the growth arrest pathway becomes apparent because apoptosis is inhibited (Fig. 81. The relationship between apoptosis and the cell cycle in this situation may be limited to the causation of p53 accumulation, perhaps because of the generation of DNA damage through aberrant or unregulated DNA synthesis. Thus, with the simultaneous activation of both growth arrest and apoptosis pathways, apoptosis is dominant over growth arrest (Fig. 8). This model would be consistent with the observation that Bcl-2 and E1B $19 \mathrm{~K}$ expression specifically block p53-dependent apoptosis while preserving the growth arrest function of $\mathrm{p} 53$.

The E1B $19 \mathrm{~K}$ protein bears a strong resemblance to Bcl-2 both in functional assays and in amino acid sequence. The $\mathrm{BH} 1$ region in particular is highly conserved in the E1B $19 \mathrm{~K}$ proteins encoded by the 12 adenovirus serotypes for which there is sequence information (Chiou et al. 1994b). The invariant glycine at codon 87 in the adenovirus 2 (Ad2) E1B $19 \mathrm{~K}$ protein is also invariant among members of the Bcl-2 family. Glycine-to-alanine substitution at this position causes a loss of the ability to inhibit apoptosis in both the ElB $19 \mathrm{~K}$ and Bcl-2 proteins (White et al. 1992; Chiou et al. 1994b; Yin et al. 1994). Interestingly, this same amino acid substitution in cither the E1B $19 \mathrm{~K}$ or Bcl-2 protein prevents interaction with Bax, suggesting a common biochemical mechanism of action. What was surprising was the identification of a third conserved region, $\mathrm{BH} 3$, that is sufficient for the interaction of Bax with either E1B 19K or Bcl-2. In contrast, the corresponding E1B $19 \mathrm{~K} \mathrm{BH} 3$ is required but not sufficient for interaction with Bax. The central conserved domain encompassing $\mathrm{BH} 1, \mathrm{BH} 2$, and $\mathrm{BH} 3$ of $\mathrm{E} 1 \mathrm{~B}$ $19 \mathrm{~K}$ is the minimal region of E1B $19 \mathrm{~K}$ sufficient for interaction with Bax BH3 (amino acids 50-78). When the region of the E1B $19 \mathrm{~K}$ protein that is sufficient for association with full-length rBax was mapped, however, $19 \mathrm{~K}$ $\mathrm{BH} 3$ (amino acids 19-57) could interact weakly, but $19 \mathrm{~K}$ $\mathrm{BH} 3$ and $\mathrm{rBax} \mathrm{BH} 3$ did not interact. Thus, the $\mathrm{BH} 3$ region of either $19 \mathrm{~K}$ or Bax may be an interaction domain for association with multiple domains $(\mathrm{BH} 1-\mathrm{BH} 3)$ on the opposite binding partner. Nonsymmetrical interactions between the $\mathrm{E} 1 \mathrm{~B} 19 \mathrm{~K}$ or $\mathrm{Bcl}-2$ and Bax proteins are therefore, likely. Participation of regions outside of $\mathrm{BH} 1$ and $\mathrm{BH} 2$ in intcractions between Bcl-2 family members was also suggested by the interaction between $\mathrm{Bcl}-\mathrm{x}_{\mathrm{S}}$ and $\mathrm{Bcl}-$ $x_{\mathrm{L}} \cdot \mathrm{Bcl}-x_{\mathrm{S}}$, which is a product of a splice variant of the $b c l \cdot x$ gene, is missing $\mathrm{BHl}$ and $\mathrm{BH} 2$ but can interact with and antagonize the function of another alternatively spliced product, $\mathrm{Bcl}-\mathrm{x}_{\mathrm{L}}$, which retains $\mathrm{BH}$ and $\mathrm{BH} 2$ (Boise et al. 1993; Sato et al. 1994). Perhaps BH3 of Bcl- $x_{5}$ confers the ability to interact with $\mathrm{BH} 1-\mathrm{BH} 3$ of $\mathrm{Bcl}-\mathrm{x}_{\mathrm{L}}$, as is the case of the interaction between Bax and E1B $19 \mathrm{~K}$.

The identification of such a small binding region $(\mathrm{BH} 3)$ that is sufficient for the interaction of Bax with either the E1B $19 \mathrm{~K}$ or Bcl-2 proteins, or for interaction of $19 \mathrm{~K}$ with Bax, may account for the large number of different proteins that have been pulled out of yeast two-hybrid assays and expression cloning for interaction with members of the Bcl-2 family (Boyd et al. 1994; Farrow et al. 1995; Takayama et al. 1995; Yang et al. 1995). At least one other 19K-binding protein (BP4) that we isolated from the two-hybrid screen has sequence homology with BH3 (J. Han and E. White, unpubl.). Whether this region is responsible for $19 \mathrm{~K}$ association or this protein has any role in the regulation of apoptosis, remains to be determined. It is conceivable that such a short sequence $i<29$ amino acids) may be represented in multiple proteins that may or may not be relevant for apoptosis. Determination that proteins interact with members of the Bcl-2 family in vivo and that the interaction has some physiological relevance may therefore be imperative.

Another Bcl-2 family member, Bak, has been shown to interact with the $19 \mathrm{~K}$ protein in yeast two-hybrid assays and may act similarly to Bax as an apoptosis regulator (Chittenden et al. 1995a; Farrow et al. 1995; Kiefer et al. 1995). Bak contains the conserved $\mathrm{BH} 3$ region but it is not yet known if the binding requirements for $19 \mathrm{~K}$ and Bak are the same as those for $19 \mathrm{~K}$ and Bax. Bak is not detectably expressed in BRK cells, whereas Bax is, suggesting that the $19 \mathrm{~K}-\mathrm{Bak}$ interaction may not be physiologically relevant in this cell type but may be important in others.

Bak, like Bax, has a BH3 domain (Fig. 1C). Analysis of Bak deletion mutants has shown that retention of the $\mathrm{BH} 3$ domain is essential for the promotion of apoptosis and for interaction with Bcl- $x_{\mathrm{L}}$ (Chittenden et al. 1995b). Furthermore, expression of a 50-amino-acid segment of $\mathrm{Bak}$, including $\mathrm{BH} 3$ but excluding $\mathrm{BH} 1$ and $\mathrm{BH} 2$, was sufficient for the induction of apoptosis (Chittenden et al. 1995b). Thus, the $\mathrm{BH} 3$ domain and sequences in the immediate vicinity encode the apoptosis-promoting activity that may act by either interacting with and interfering with a Bcl-2-like activity or through possession of an effector activity. Presumably Bax functions analogously.

The E1B $19 \mathrm{~K}$ protein has been shown to interact with Bax in yeast two-hybrid assays, and both will coimmunoprecipitate when synthesized in vitro. The specificity of the $19 \mathrm{~K}-\mathrm{Bax}$ interaction is remarkable in that singleamino-acid substitutions at codons 87 (in BHl) and 51 (in BH3) of the $19 \mathrm{~K}$ protein abrogate the interaction. In GST pulldown assays, in vitro-translated Bax associates with 19K-GST but not with the BH3 missense mutant pm51GST. More importantly, GST-19K but not GST-pm51 will act as an affinity resin to isolate Bax from crude cell lysates. In GST-19K pulldown assays using $\left[{ }^{35} \mathrm{~S}\right]$ methio- 
nine-labeled extracts, a protein that comigrates with Bax is virtually the only protein that was specifically isolated based on the ability to interact with the $19 \mathrm{~K}$ protein. Thus, the interaction between the E1B $19 \mathrm{~K}$ and Bax proteins is highly specific and can occur in the complex milieu of a crude cell lysate. The $19 \mathrm{~K}$ protein is highly insoluble and is only liberated by the presence of ionic detergents that would normally destroy protein-protein interactions (White et al. 1984; White and Cipriani 1990). We have therefore not been able to coimmunoprecipitate E1B 19K with Bax (or any other protein) in cell lysates. The GST-19K pulldown assays with whole cell extracts as a source of Bax may be the only means to evaluate the potential for an in vivo interaction.

In BRK cells Bax appears to be sufficient for the induction of apoptosis. By binding to and neutralizing Bax, the E1B $19 \mathrm{~K}$ and Bcl-2 proteins could act as apoptosis inhibitors. E1B 19K and Bcl-2 expression have no measurable effect on cell growth or viability, but their activity becomes apparent when Bax is present, suggesting that Bax is the effector of cell death. The functional outcome of $\mathrm{Bax}$ and $\mathrm{Bcl}-2$ expression (cell death vs, protection from cell death), however, may depend on the presence of other Bcl-2 family members and the nature of the interactions between them. Presumably, the Bcl-2 family acts either directly or indirectly as regulators of the ICE family, and it will be of interest to determine which cysteine protease is activated by Bax or inhibited by $\mathrm{E} 1 \mathrm{~B} 19 \mathrm{~K}$ and $\mathrm{Bcl}-2$. Finally, defining the specific interaction domains such as $\mathrm{BH} 3$ may identify new targets for anti-cancer therapy.

\section{Materials and methods}

\section{Two-hybrid system}

A HeLa cDNA library in the pGAD - GH vector (Hannon ct al. 1993) was screened in the ycast strain YGH1 (ura3-25, his3-200, ade2-101, Jys-2-801, trp1-901, Ien2-3, $\mathrm{Can}^{\mathrm{r}}$, gal4-542, gal80-538, LYS2::gal1 ${ }_{\text {uas }}-g a l 1_{\mathrm{tata}}-$ HIS3, URA3:gal1-lacZ). The pGBT-9$19 \mathrm{~K}$ plasmid was cotransfected with the pGAD library plasmid using standard lithium acetate transfection procedures. Transformants were plated on ycast dropout plates lacking leucine, tryptophan, and histidine. Approximately $3 \times 10^{6}$ transformants were screened for growth in the absence of histidine and assayed for $\beta$-galactosidase activity, as a second reporter, using a filter-based assay (Hannon et al. 1993). The library plasmid was selectively recovered by transforming yeast mini prep DNA into Escherichia coli $\mathrm{MH} 4$ which is len $B^{-}$and therefore selects for the leucine metabolic marker on the pGAD plasmid (Hannon et al. 1993). False-positives were eliminated by screening for interaction with irrelevant proteins (Apc-2) and the empty pGBT-9 vector. Sequence analysis of the cDNAs encoding the interacting proteins was performed using Sequenase 2.0 /U.S. Biochemicall according to the manufacturer's specifications.

\section{$P C R$ amplification and cloning}

Cytoplasmic RNA was extracted from the Anl cell lines after incubation for $4 \mathrm{hr}$ at $32^{\circ} \mathrm{C}$ using previously described methods (Sabbatini et al. 1995; White et al. 1986) and reverse transcribed with Moloney murine lymphotrophic virus reverse transcriptase (GIBCO-BRL). To clone rat Bax $\alpha$, the complementary
DNA was resuspended in a total volume of $100 \mu$ containing 2.5 units of Taq DNA polymerase (Perkin-Elmer), $20 \mu \mathrm{M}$ each of dGTP, dATP, dTTP, and dCTP, 50 pmoles of forward primer (5'-TAATACCCGGGTATGGACGGGTCCGGGGAGC-3') and reverse primer $\mid 5^{\prime}$-CGCTGCTCGAGTCAGCCCATCTTCTTCCAGAT $\left.-3^{\prime}\right)$, and $1 \times$ reaction buffer. Thirty-five amplification cycles consisted of denaturation at $94^{\circ} \mathrm{C}$ for $1 \mathrm{~min}$ (first cycle $4 \mathrm{~min}$; annealing at $58^{\circ} \mathrm{C}$ for $1 \mathrm{~min}$, and extension at $72^{\circ} \mathrm{C}$ for $2 \mathrm{~min}$. PCR products were size fractionated by $1.2 \%$ agarose electrophoresis, and the expected 598 -bp product was purified, digested with $X \mathrm{maI}$ and $X$ hol, and ligated into the pGAD-GH vector. The insert was sequenced to verify that it encoded $\mathrm{rBax}$. The amino acid sequence of $\mathrm{rBax}$ had $91.7 \%$ identity $195.3 \%$ similarity $\mid$ with full length hBax and $93.1 \%$ identity $(96.6 \%$ similarity $)$ with $\mathrm{BH} 3$ of hBax.

\section{Plasmid construction}

A 552-bp fragment containing the wild-type E1B $19 \mathrm{~K}$ open reading frame was PCR cloned from the pCMV19K expression vector (White and Cipriani 1989) into the pGBT-9 plasmid in frame with the DNA-binding domain of GAL4. A specific 5' primer was used to engineer an EcoRI site before the ATG and the M13 reverse primer served as the $3^{\prime}$ primer. The fragment was cloned into the EcoRI and BamHI sites of the pGBT9 vector. Standard $P C R$ reactions were used to construct yeast fusion plasmids (Bp3-Ex3/4' in pGAD-GH and Bp3-Ex3 in pGAD-GH). The PCR products were digested with $X \mathrm{mal}$ and $\mathrm{Xhol}$ and ligated in pGAD-GH.

cDNAs encoding the E1B $19 \mathrm{~K}$ missense mutants pm7, pm44, pm5l, pm87, and pm102 (White et al. 1992; Chiou et al. 1994b) were digested with EcoRI and BamHI. The 552-bp ElB $19 \mathrm{~K}$ mutant open reading frames were then cloned in frame with the DNA-binding domain of pGBT9. Standard PCR techniques were used to construct the ElB $19 \mathrm{~K}$ deletion mutants. The primers were designed to include an EcoRI site at the $5^{\prime}$ end and a BamHI site at the $3^{\prime}$ end to clone the fragments in-frame with the DNA-binding domain of the pGBT-9 vector.

To produce the rBax mammalian expression vector pCEP4Myc-rBax, oligonucleotides encoding a Myc epitope tag with flanking $K p n I$ and XmaI sitcs were annealed with the $r b a x$ cDNA containing flanking $X m a I$ and $X h o I$ sites and ligated into the pCEP4 vector that had been digested with KpnI and XhoI. This placed the Myc epitope tag in frame at the amino terminus of $r B a x$. The E1B 19K expression vector pcDNA3-19K was constructed by ligating the $19 \mathrm{~K}$ coding region into the HindIII site of pcDNA3. The orientation of the insert was confirmed by digestion with KpnI. Myc-rBax was also cloned into the Kpni and $X$ hoI sites of pcDNA3 to generate the $\mathrm{p} T 7-\mathrm{Myc}-\mathrm{rBax}$ vector for in vitro transcription and translation of Bax. The human $b c l-2$ under the control of the $T 7$ promoter was constructed by cloning bcl-2 into the EcoRI site of pGEM-2 to generate pGEM2-Bcl-2 (kindly provided by Dr. C. Gelinas, University of Medicine and Dentistry of New Jersey. (UMDNI)). The E1B 19K open reading frame and the $19 \mathrm{~K}$ mutant pm51 were subcloned from thcir respective pGBT 9 plasmids by restriction digestion with the EcoRI and SalI into the pGEX-4Tl plasmid to generate pGST19K and pGSTpm51. The 5' EcoRI site maintained the frame to read through into a GST fusion protein. For construction of the pT719K expression vector, a unique $N d e \mathrm{I}$ site was created at the ATG of the ElB $19 \mathrm{~K}$ open reading frame by sitedirected mutagenesis. A fragment containing the $19 \mathrm{~K}$ open reading frame (nucleotides 1711-2256 of the adenovirus genomel was then subcloned into a $\mathrm{T} 7$ promoter expression vector (generously provided by Drs. O. W. Studier and J. Dunn, Brookhaven National Laboratory, NY). The pT719K construct also contained a stop codon in the overlapping E1B $55 \mathrm{~K}$ reading 
frame from the pMT19K construct (White and Cipriani 1989) to prevent expression of other EiB products.

\section{Antibodies}

Monoclonal antibodies directed against the E1B $19 \mathrm{~K}$ protein were generated by immunizing mice with full-length ElB $19 \mathrm{~K}$ protein purified from E. coli. The $\mathrm{p} T 719 \mathrm{~K}$ vector was transformed into the BL21 DE3 E. coli strain, and the $19 \mathrm{~K}$ protein was purified by standard chromatographic procedures. The purified protein was used to immunize BALB/c mice, and hybridomas were generated by standard protocols (Harlow and Lane 1988). The $19 \mathrm{~K}$-specific hybridoma $2 \mathrm{~F} 3$ was injected into mice to obtain ascites fluid. Polyclonal antibodies directed against $\mathrm{Bax}(\mathrm{N}-20)$ and Bcl-2 $(\Delta \mathrm{C}-21)$ were purchased from Santa Cruz Biotechnology, Inc. (Santa Cruz, CA). The monoclonal Myc antibody- 1 was purchased from Oncogene Science, Inc. $\mid \mathrm{Cam}-$ bridge, MA). A polyclonal antibody directed against the E $1 \mathrm{~B} 19 \mathrm{~K}$ protein $(\mathrm{p} 21)$ and a monoclonal antibody directed against the E1B 55K protein (13D2) have been described previously (White and Cipriani 1989; White and Cipriani 1990|. The monoclonal antibody directed against murine $21 /$ Waf-1/Cip-1 was a kind gift from Dr. David Hill of Oncogene Science, Inc. (Cambridge, MA!. An anti-actin monoclonal antibody was purchased from Amersham Corp. (Arlington, IL). An anti-rBcl-2 (1632-15) polyclonal antibody that also cross-reacts with hBcl-2 was kindly provided by Dr. J. Reed (La Jolla Cancer Research Foundation, La Jolla, CA).

\section{In vitro protein interaction assays}

mRNAs encoding human Bcl-2 (pGEM-2-Bcl-2), ElB 19K (pcDNA3-19K), and rBax (pcDNA3-rBax) were prepared by in vitro transcription. mRNAs were titrated to generate equal quantities of translated protein products. The in vitro transcription and translation were performed using a commercial kit (Promega). The ${ }^{35} \mathrm{~S}$-labeled proteins were incubated for $2 \mathrm{hr}$ with anti-Bcl-2 $(\Delta \mathrm{C} 21)$, anti-Bax $(\mathrm{N}-20)$, or anti-19K (p21) antibodies in immunoprecipitation buffer $[50 \mathrm{~mm}$ Tris $(\mathrm{pH} 7.5), 150 \mathrm{~mm}$ $\mathrm{NaCl}$, and $0.2 \% \mathrm{NP}-40$ and washed three times with the same buffer containing $0.01 \%$ NP-40. The immunoprecipitated proteins were analyzed on $17 \%$ SDS gels. Gels were fixed in $50 \%$ methanol and $10 \%$ glacial acetic acid for $2 \mathrm{hr}$, dried, and scanncd using a PhosphorImager (Molecular Dynamics).

For fusion protein binding assays, plasmids were transformed into BL21 DE3 and induced with $0.5 \mathrm{~mm}$ of isopropyl- $\beta-\mathrm{D}$ thiogalactoside. A 50- $\mu$ l aliquot of culture was analyzed by SDSPAGE to evaluate fusion protein induction. The remaining culture was sonicated on ice by using 10 short bursts at 10 sec each (Fischer Sonic Dismembranator 3000 ), clarified by centrifugation, and the supernatant was resuspended in $50 \%$ (vol/vol) glutathione-Sepharose beads (Pharmacia Biotech, Piscataway, NII. An aliquot of the protein bound beads was analyzed by SDS-PAGE to ensure equal amounts of pure fusion protein were present.

In vitro binding assays were performed by incubating equal amounts of GST, GST-19K, and GST-pm51 (see Fig. 3B), immobilized onto glutathione-Sepharose beads, with in vitrotranslated $\mathrm{rBax}$ or $\mathrm{hBcl}-2$ proteins diluted in $0.5 \mathrm{ml}$ of NETN buffer $[20 \mathrm{~mm}$ Tris $|\mathrm{pH} 8.0|, 100 \mathrm{mM} \mathrm{NaCl}, 1 \mathrm{~mm}$ EDTA, $0.2 \%$ NP-40]. The mixture was incubated for $2 \mathrm{hr}$ at $4^{\circ} \mathrm{C}$, washed three times with NETN buffer, and resuspended in $2 \times$ Laemmli buffer. $\mathrm{rBax}$ and $\mathrm{hBcl}-2$ proteins translated in vitro werc also immunoprecipitated with anti-Myc, anti-Bcl-2, or anti-ElB 55K antibodies to determine the relative levels of protein produc- tion. All samples were boiled for $5 \mathrm{~min}$, and proteins were resolved by $15 \%$ SDS-PAGE and analyzed as described above.

For detection of the ElB $19 \mathrm{~K}$ and rBax interaction in cell lysates, the E1A plus tsp53ival135|-transformed cell line An1 (Debbas and White 1993) was plated at $95 \%$ confluence and incubated at the permissive temperature $\left(32^{\circ} \mathrm{C}\right)$ for $14 \mathrm{hr}$. Cells were washed with PBS and lysed in $1 \mathrm{ml}$ of cold NETN lysis buffer containing protease inhibitors $10.1 \mathrm{~mm}$ phenymethyl sulfonylfluoride, $10 \mathrm{~mm}$ benzamidine, $0.1 \mathrm{mg} / \mathrm{ml}$ of bacitracin, 1.0 $\mu \mathrm{g} / \mathrm{ml}$ of pepstatin A, $10 \mathrm{~mm}$ sodium bisulfite) for $20 \mathrm{~min}$. Cells were centrifuged at $10 \mathrm{~K}$ for $10 \mathrm{~min}$ to remove cellular debris. The lysates were then incubated with GST, GST-19K, and GST-pm51 proteins bound to glutathione-Sepharose beads for $2 \mathrm{hr}$ and washed as described above. Samples were resolved by $15 \%$ SDS-PAGE. rBax was detected by Western blot analysis using a Bax-specific polyclonal antibody (N-20).

Binding assays with labeled cell extracts were performed by incubating the An 1 cell line at $32^{\circ} \mathrm{C}$ for $12 \mathrm{hr}$, with methioninedeficient media in the presence of $i^{35}$ S/methionine for $4 \mathrm{hr}$. The cells were lysed in NETN buffer and incubated with GST and GST-19K fusion proteins and washed, as described above. Samples were resolved by SDS-PAGE and fixed and fluorographed by standard procedures.

\section{Inditect immunofIuorescence}

$19 \mathrm{Kl}$, the ElA plus tsp53|val135\}-transformed BRK line that expresses the E1B 19K protein (Debbas and White 1993), was plated at $90 \%$ confluence at the restrictive temperature $\left(38.5^{\circ} \mathrm{C}\right)$ and incubated at $32^{\circ} \mathrm{C}$ for $72 \mathrm{hr}$. The $19 \mathrm{Kl}$ cell line was electroporated with $10 \mu \mathrm{g}$ of the CMV Myc-tagged Bax expression vector (pCEP4-Myc-rBax) and incubated at $32^{\circ} \mathrm{C}$. Cells were fixed with methanol $48 \mathrm{hr}$ post-transfection and double-labeled with an anti-Myc monoclonal antibody at a 1:5 dilution and an anti-19K polyclonal antibody at a 1:200 dilution. Antibodies were visualized with goat anti-mouse rhodamine-conjugated and goat anti-rabbit fluorescein-conjugated secondary antibodies.

A TdT assay (Gavrieli et al. 1992) was utilized as an indicator of apoptotic cell death. $19 \mathrm{Kl}$ cells grown on coverslips were incubated at $38.5^{\circ} \mathrm{C}$ and transfected with $20 \mu \mathrm{g}$ of either pCEP4 vector or pCEP4-Myc-rBax and then incubated for an additional $48 \mathrm{hr}$ to permit Bax protein expression. The cells were then fixed with $2 \%$ paraformaldehyde in PBS followed by $70 \%$ ethanol and incubated with biotinylated dUTP and TdT 0.3 cnzymatic units/ml, Boehringer Mannheim Biochemicals) as described previously (Gavrieli et al. 1992). Cells were washed with $0.125 \%$ BSA in PBS, incubated with avidin-FITC, and visualized by epifluorescence microscopy.

\section{Bax functional assays}

To examine Bax function in transient expression assays, the pcDNA3-19K construct was cotransfected with pCEP4-MycrBax into the An1 cell line by electroporation as described previously (Chiou et al. 1994a). The amount of transfected pcDNA3-19K DNA was fixed at $10 \mu \mathrm{g}$, and was cotransfected with $1,5,10$, and $20 \mu \mathrm{g}$ of control vector or pCEP4-Myc-rBax DNA. The Anl cell line was also transfected with pCEP4-Myc$\mathrm{rBax}$ vector alone at the same concentration. The transfected cells were incubated at $38.5^{\circ} \mathrm{C}$ for $60 \mathrm{hr}$ and shifted to $32^{\circ} \mathrm{C}$ for $60 \mathrm{hr}$. The viable cell number was assessed by trypan blue exclusion. For colony formation assays, the Anl cell line was transfected with $0.5,1$, and $5 \mu \mathrm{g}$ of linerized pCEP4-Myc-rBax plasmid by electroporation. Stable cell lines were maintained at $38.5^{\circ} \mathrm{C}$ and selected by the addition of hygromycin to the me- 
dium $\left(2 \times 10^{6} \mathrm{U} / \mathrm{ml}\right.$ of medium $)$, and the foci number was determined by Giemsa staining at 21 days post-transfection.

\section{Northern blot analysis}

Cytoplasmic RNA was extracted from cell lines at the restrictive temperature $\left(38.5^{\circ} \mathrm{C}, 0\right.$-hour time point $)$ and after 4 and $9 \mathrm{hr}$ incubation at the permissive temperature $\left(32^{\circ} \mathrm{C}\right)$ using methods described previously (Sabbatini et al. 1995b). Twenty micrograms of cytoplasmic RN $\wedge$ from each cell line was subjected to Northern blot analysis. The probes used for Northern blot analysis were an oligonucleotide $\left[5^{\prime}\right.$-CTGCAGCTCCATATTGCTGTCCAGTTCATCTCCAATTCGCCGGAG-3') specific for a region within exon 3 of $r b a x$, and full-length cDNAs corresponding to mouse p21/Waf-1/Cip-1, and $\beta$-actin. Northern blots were scanned using a PhosphorInnager |Molecular Dynamics!.

\section{Western blotting}

Cell extracts for Western blot analysis were prepared from subconfluent cultures, and $80 \mu \mathrm{g}$ of protein from each cell line was analyzed by SDS-PAGE and semidry blotting onto nitrocellulose membranes by standard procedures. Immune complexes were detected by enhanced chemiluminescence (ECL) according to the manufacturer's specifications (Amersham).

\section{Acknowledgments}

We thank Drs. Linda Van Aelst, Maria Fernandez-Sarabia, and Jim Bishoff for providing the HeLa cell cDNA library in pGAD$\mathrm{GH}$, Dr. Céline Gélinas for providing human $b c l-2$ in pGEM-2, Dr. P. Verwaerde for constructing the pGBT9-19K vector, and Dr. Diane Harvey for construction of the pT $719 \mathrm{~K}$ expression vector. We also thank Dr. John Reed for providing a Bcl-2 antibody and Drs. S. Chiou and G. Kasof for helpful comments and suggestions. This work was supported by grants from The $\mathrm{Na}$ tional Institutes of Health (CA53370 and CA60088) to E.W. P.S. was supported in part by a Center for Advanced Biotechnology and Medicine (CABM) predoctoral fellowship.

The publication costs of this article were defrayed in part by payment of page charges. This article must therefore be hereby marked "advertisement" in accordance with 18 USC section 1734 solely to indicate this fact.

\section{References}

Amati, B., T.D. Littlewood, G.I. Evan, and H. Land. 1993. The c-myc protein induces cell cyclc progresssion and apoptosis through dimerization with Max. EMBO I. 12: 5083-5087.

Askew, D.S., R. A. Ashmun, B.C. Simmons, and J.L. Cleveland. 1991. Constitutive c-myc expression in an IL-3-dependent myeloid cell line suppresses cell cycle arrest and accelerates apoptosis. Oncogene 6: 1915-1922.

Boise, L.H., M. Gonzalez-Garcia, C.E. Postema, L. Ding, T. Lindsten, L.A. Turka, X. Mao, G. Nuñez, and C. Thompson. 1993. $b c l-x$, a $b c l-2$-related gene that functions as a dominant regulator of apoptotic death. Cell 74: 597-608.

Boyd, J., S. Malstrom, T. Subramanian, L. Venkatesh, U. Schaeper, B. Elangovan, C. D'Sa-Eipper, and G. Chinnadurai. 1994. Adenovirus E1B $19 \mathrm{kDa}$ and bcl-2 proteins interact with a common set of cellular proteins. Cell 79: 341-351.

Caelles, C., A. Helmberg, and M. Karin. 1994. p53-dependent apoptosis in the absence of transcriptional activation of $\mathrm{p} 53$ target genes. Nature 370: 220-223.
Canman, C., T.M. Gilmer, S.B. Coutts, and M.B. Kastan. 1995. Growth factor modulation of p53-mediated growth arrest versus apoptosis. Genes \& Dev. 9: 600-611.

Chiou, S.-K., L. Rao, and E. White. 1994a. Bcl-2 blocks p53dependent apoptosis. Mol. Cell. Biol. 14: 2556-2563.

Chiou, S.K., C.C. Tseng, L. Rao, and E. White. 1994b. Functional complementation of the adenovirus E1B $19 \mathrm{~K}$ protein with Bcl-2 in the inhibition of apoptosis in infected cells. $J$. Virol. 68: 6553-6566.

Chittenden, T., C. Flemmington, A.B. Houghton, R.G. Ebb, G.J. Gallo, B. Elangovan, G. Chinnadurai, and R.J. Lutz. 1995a. A conserved domain in Bak, distinct from $\mathrm{BHl}$ and $\mathrm{BH} 2$, mediates cell death and protein binding functions. EMBO J., |in press).

Chittenden, T., E.A. Harrington, R. O'Connor, C. Flemington, R.J. Lutz, G.I. Evan, and B.C. Guild. 1995b. Induction of apoptosis by the Bcl-2 homologue Bak. Nature 374: 733-736.

Cleary, M.L., S.D. Smith, and J. Sklar. 1986. Cloning and structural analysis of cDNAs for bcl-2 and a hybrid bcl-2/immunoglobulin transcript resulting from the $t\{14 ; 18\}$ translocation. Cell 47: 19-28.

Clem, R.J., and L.K. Miller. 1994. Control of programmed cell death by the baculovirus genes p35 and iap. Mol. Cell. Biol. 14: $5212-5222$.

Debbas, M., and E. White. 1993. Wild-type p53 mediates apoptosis by E1A, which is inhibited by ElB. Genes \& Dev. 7: 546-554.

El-Deiry, W.S., T. Tokino, V.E. Velculescu, D.B. Levy, R. Parsons, J.M. Trent, D. Lin, E. Mercer, K.W. Kinzler, and B. Vogelstein. 1993. WAF1, a potential mediator of p53 tumor suppression. Cell 75: 817-825.

Evan, G.I., A.H. Wyllie, C.S. Gilbert, T.D. Littlewood, H. Land, M. Brooks, C.M. Waters, L.Z. Penn, and D.C. Hancock. 1992. Induction of apoptosis in fibroblasts by c-myc protein. Cell 69: $119-128$.

Farrow, S.N., I.H.M. White, I. Martinou, T. Raven, K.-T. Pun, C.J. Grinham, J.-C. Martinou, and R. Brown. 1995. Cloning of a bcl-2 homologue by interaction with adenovirus E1B 19K. Nature 374: 731-733.

Gavrieli, Y., Y. Sherman, and S.A. Ben-Sasson. 1992. Identification of programmed cell death in situ via specific labeling of nuclear LNA fragmentation. /. Cell Biol. 119: 493-501.

Gooding, L.R., L. Aquino, P.J. Duerksen-Hughes, D. Day, T.M. Horton, S. Yei, and W.S.M. Wold. 1991. The E1B-19K protein of group $C$ adenoviruses prevents cytolysis by tumor necrosis factor of human cells but not mouse cells. I. Virol. 65: 3083-3094.

Hannon, G., D. Demetrick, and D. Beach. 1993. Isolation of the Rb-related p130 through its interaction with $\mathrm{cdk} 2$ and $\mathrm{cy}$ clins. Genes \& Dev. 7: 2378-2391.

Harlow, E., and D. Lane. 1988. Antibodies: A Laboratory Manual. Cold Spring Harbor Laboratory, Cold Spring Harbor, New York.

Harper, J.W., G.R. Adami, N. Wei, K. Keyomarsi, and S.J. Elledge. 1993. The p2l cdk-interacting protein cipl is a potent inhibitor of Gl cyclin-dependent kinases. Cell 75: 805816.

Hashimoto, S., A. Ishii, and S. Yonehara. 1991. The E1B oncogene of adenovirus confers cellular resistance to cytotoxicity of tumor necrosis factor and monoclonal anti-Fas antibody. Int. Immunol 3: 343-351.

Haupt, Y., S. Rowan, E. Shaulian, K. Vousden, and M. Oren. 1995. Induction of apoptosis in HeLa cells by trans-activation-deficient p53. Genes \& Dev. 9: 2170-2183.

Henderson, S., D. Huen, M. Rowe, C. Dawson, G. Johnson, and A. Rickinson. 1993. Epstein-Barr virus-coded BHRF1 pro- 
tein, a viral homologue of Bcl-2, protects human B cells from programmed cell death. Proc. Natl. Acad. Sci. 90: 8479 8483.

Hermeking, H., and D. Eick. 1994. Mediation of c-Myc-induced apoptosis by p53. Science 265: 2091-2093.

Hollstein, M., D. Sidransky, B. Vogelstein, and C. Harris. 1991. p53 mutations in human cancers. Science 253: 49-53.

Kastan, M.B., O. Onyekwere, D. Sidransky, B. Vogelstein, and R.W. Craig. 1991. Participation of p53 protein in the cellular response to DNA damage. Cancer Res. 51: 6304-6311.

Kastan, M.B., Q. Zhan, W.S. El-Deiry, F. Carrier, T. Jacks, W.V. Walsh, B.S. Plunkett, B. Vogelstein, and A.J. Fornace. 1992. A mammalian cell cycle checkpoint pathway utilizing p53 and GADD45 is defective in ataxia-telangiectasia. Cell 13: 587597.

Kiefer, M.C., M.J. Brauer, V.C. Powers, J.J. Wu, S.R. Umansky, L.D. Tomei, and P.J. Barr. 1995. Modulation of apoptosis by the widely distributed Bcl-2 homolgue Bak. Nature 374: 736-739.

Kuerbitz, S.J., B.S. Plunkett, W.V. Walsh, and M.B. Kastan. 1992. Wild-type p53 is a cell cycle checkpoint determinant following irradiation. Proc. Natl. Acad. Sci. 89: 7491-7495.

Lin, H.-J.L., V. Eivner, G.C. Prendergast, and E. White. 1995. Activated $\mathrm{H}$-ras rescues $\mathrm{E} 1 \mathrm{~A}$-induced apoptosis and cooperates with E1A to overcome p53-dependent growth arrest. Mol. Cell. Biol. 15: 4536-4544.

Lin, J., J. Chen, B. Elenbaas, and A.J. Levine. 1994. Several hydrophobic amino acids in the p53 amino-terminal domain are required for transcriptional activation, binding to $\mathrm{mdm}-2$ and the adenovirus 5 ElB $55-\mathrm{kD}$ protein. Genes \& Dev. 8: $1235-1246$.

Lowe, S., and H.E. Ruley. 1993. Stabilization of the p53 tumor suppressor is induced by adenovirus- $5 \mathrm{E} 1 \mathrm{~A}$ and accompanies apoptosis. Genes \& Dev. 7: 535-545.

Lowe, S.W., T. Jacks, D.E. Housman, and E.H. Ruley. 1994. Abrogation of oncogene-associated apoptosis allows transformation of p53-deficient cells. Proc. Natl. Acad. Sci. 91: 2026-2030.

Maltzman, W., and L. Czyzyk. 1984. UV irradiation stimulates levels of p53 cellular tumor antigen in nontransformed mouse cells. Mol. Cell. Biol. 4: 1689-1694.

Miyashita, T., and J.C. Reed. 1995. Tumor suppressor p53 is a direct transcriptional activator of the human bax gene. Cell 80: 293-299.

Miyashita, T., S. Krajewski, M. Krajewska, H.G. Wang, H.K. Lin, D.A. Liebermann, B. Hoffman, and J.C. Reed. 1994. Tumor suppressor p53 is a regulator of bcl-2 and bax gene expression in vitro and in vivo. Oncogene 9: 1799-1805.

Moran, E. 1993. DNA tumor virus transforming proteins and the cell cycle. Curr. Opin. Genet. Dev. 3: 63-70.

Mymryk, J. S., K. Shire, and S.T. Bayley. 1994. Induction of apoptosis by adenovirus type $5 \mathrm{ElA}$ in rat cells requires a proliferation block. Oncogene 9: 1187-1193.

Neilan, J.G., Z. Lu, C.L. Afonzo, G.F. Kutish, M.D. Sussman, and D.L. Rock. 1993. An african swine fever virus gene with similarity to the proto-oncogene $b c l-2$ and the Epstein-Barr virus gene BHRF1. I. Virol. 67: 4391-4394.

Noda, A., Y. Ning, S.F. Venable, O.M. Pereira-Smith, and J.R. Smith. 1994. Cloning of senecent cell-derived inhibitors of DNA synthesis using and expression screen. Exp. Cell. Res. 211: 90-98.

Oltvai, Z.N., C.L. Millman, and S.J. Korsmeyer. 1993. Bcl-2 heterodimerizes in vivo with a conserved homolog, Bax, that accelerates programmed cell death. Cell 74: 609-619.

Prives, C. 1994. How loops, $\beta$ sheets, and $\alpha$ helices help us to understand p53. Cell 78: 543-546.
Rao, L., M. Debbas, P. Sabbatini, D. Hockenberry, S. Korsmeyer, and E. White. 1992. The adenovirus ElA proteins induce apoptosis which is inhibited by the E1B $19 \mathrm{~K}$ and Bcl-2 proteins. Proc. Natl. Acad. Sci. 89: 7742-7746.

Ray, C.A., R.A. Black, S.R. Kronheim, T.A. Greenstreet, P.R Sleath, G.S. Salvesen, and D.J. Pickup. 1992. Viral inhibition of inflammation: Cowpox virus encodes an inhibitor of the interleukin-1 $\beta$ converting enzyme. Cell 69: 597-604.

Sabbatini, P., S.-K. Chiou, L. Rao, and E. White. 1995a. Modulation of $\mathrm{p} 53$-mediated transcription and apoptosis by the adenovirus E1B 19K protein. Mol. Cell. Biol. 15: 1060-1070.

Sabbatini, P., J. Lin, A.J. Levine, and E. White. 1995b. Essential role for p53-mediated transcription in apoptosis but not growth suppression. Genes \& Dev. 9: 2184-2192.

Sarnow, P., Y.S. Ho, J. Williams, and A.J. Levine. 1982. Adenovirus E1b-58 kd tumor antigen and SV40 large tumor antigen are physically associated with the same $54 \mathrm{kd}$ cellular protein in transformed cells. Cell 28: 387-394.

Sato, T., M. Hanada, S. Bodrug, S. Irie, N. Iwama, L. Boise, C.B. Thompson, E. Golemis, L. Fong, H.-G. Wang, and J.C. Reed. 1994. Interactions among members of the Bcl-2 family analyzed with a yeast two-hybrid system. Proc. Nat1. Acad. Sci. 91: 9238-9242.

Takayama, S., T. Sato, S. Krajewski, K. Kochel, S. Irie, J.A. Millan, and J.C. Reed. 1995. Cloning and functional analysis of Bag-1: A novel Bcl-2-binding protein with anti-cell death activity. Cell 80: 279-284.

Tarodi, B., T. Subramanian, and G. Chinnadurai. 1993. Functional similarity between adenovirus E1B $19 \mathrm{~K}$ gene and Bcl-2 oncogene: Mutant complementation and suppression of cell death induced by DNA damaging agents. Int. J. Oncol. 3: 467-472.

Teodoro, J.G., G.C. Shore, and P.E. Branton. 1995. Adenovirus ElA proteins induce apoptosis by both p53-dependent and p53-independent mechanisms. Oncogene 11: 467-474.

Vogelstein, B. 1990. A deadly inheritance. Nature 348: 681-682.

White, E. 1994. Function of the adenovirus E1B oncogene in infected and transformed cells. In Seminars in virology led. E. Fanningl, pp. 341-348. Academic Press, London, UK 1995. Regulation of p53-dependent apoptosis by E1A and E1B. In Current topics in microbiology and immunology: The molecular repertoire of adenovirus led. W. Doerfler), pp. 33-58. Springer Verlag, Berlin, Germany.

White, E. and R. Cipriani. 1989. Specific disruption of intermediate filaments and the nuclear lamina by the $19-\mathrm{kDa}$ product of the adenovirus E1B oncogene. Proc. Natl. Acad. Sci. 86: $9886-9890$.

1990. Role of adenovirus E1B proteins in transformation: Altered organization of intermediate filaments in transformed cells that express the 19-kilodalton protein. Mol. Cell. Biol. 10: 120-130.

White, E. and L.R. Gooding. 1994. Regulation of apoptosis by human adenoviruses. In Apoptosis: The molecular basis for cell death II (ed. D. T. a. F. Cope), pp. 111-141. Cold Spring Harbor Laboratory Press, Cold Spring Harbor, New York.

White, E., and B. Stillman. 1987. Expression of the adenovirus ElB mutant phenotypes is dependent on the host cell and on synthesis of E1A proteins. J. Virol. 61: 426-435.

White, E., S.H. Blose, and B. Stillman. 1984. Nuclear envelope localization of an adenovirus tumor antigen maintains the integrity of cellular DNA. Mol. Cell. Biol. 4: 2865-2875.

White, E., B. Faha, and B. Stillman. 1986. Regulation of adenovirus gene expression in human WI38 cells by an ElB-encoded tumor antigen. Mol. Cell. Biol. 6: 3763-3773.

White, E., R. Cipriani, P. Sabbatini, and A. Denton. 1991. The adenovirus E1B 19-Kilodalton protein overcomes the cyto- 
toxicity of ElA proteins. J. Virol. 65: 2968-2978.

White, E., P. Sabbatini, M. Debbas, W.S.M. Wold, D.I. Kusher, and L. Gooding. 1992. The 19-kilodalton adenovirus E1B transforming protein inhibits programmed cell death and prevents cytolysis by tumor necrosis factor $\alpha$. Mol. Cell. Biol. 12: 2570-2580.

Xiong, Y., G. Hannon, H. Zhang, D. Casso, R. Kobayashi, and D. Beach. 1993. p21 is a universal inhibitor of cyclin kinases. Nature 366: 701-704.

Yang, E., J. Zha, J. Jockel, L.H. Boise, C.B. Thompson, and S.J. Korsmeyer. 1995. Bad, a heterodimeric partner for Bcl-xL and Bcl-2, displaces Bax and promotes cell death. Cell 80: 285291.

Yew, P.R., and A.J. Berk. 1992. Inhibition of p53 transactivation required for transformation by adenovirus early $1 \mathrm{~B}$ protein. Nature 357: 82-85.

Yin, X.-M., Z. Oltvai, and S. Korsmeyer. 1994. BH1 and BH2 domains of Bcl-2 are required for inhibition of apoptosis and heterodimerization with Bax. Nature 369: 321-323.

Yonish-Rouach, E., D. Grunwald, S. Wilder, A. Kimchi, E. May, J.-J. Lawrence, P. May, and M. Oren. 1993. p53-mediated cell death: relationship to cell cycle control. Mol. Cell. Biol. 13: 1415-1423.

Yonish-Rouach, E., D. Resnitzky, J. Lotem, L. Sachs, A. Kimchi, and M. Oren. 1991. Wild-type p53 induces apoptosis of myeloid leukaemic cells that is inhibited by interleukin-6. $\mathrm{Na}$ ture 352: 345-347. 


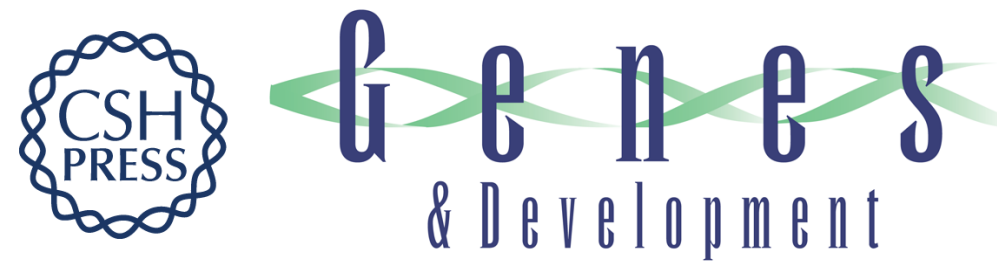

\section{The E1B 19K protein blocks apoptosis by interacting with and inhibiting the p53-inducible and death-promoting Bax protein.}

J Han, P Sabbatini, D Perez, et al.

Genes Dev. 1996, 10:

Access the most recent version at doi:10.1101/gad.10.4.461

References This article cites 64 articles, 32 of which can be accessed free at: http://genesdev.cshlp.org/content/10/4/461.full.html\#ref-list-1

License

Email Alerting

Service

Receive free email alerts when new articles cite this article - sign up in the box at the top right corner of the article or click here.

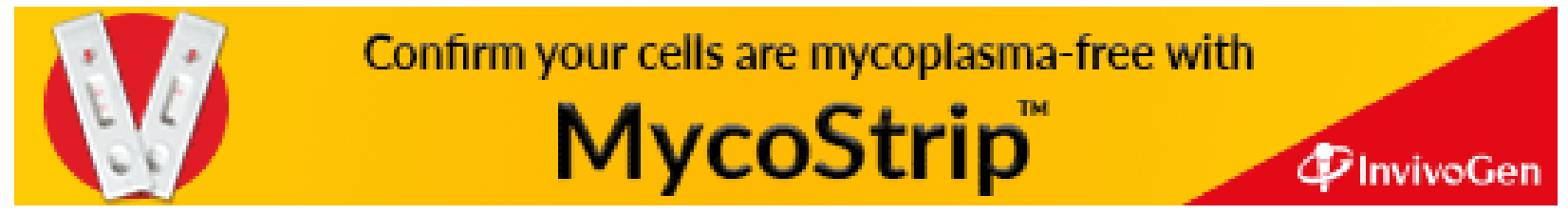

